\title{
ثرامقهاكن مالكيو
}

1 الدون مانكم جكلو دجاتهكم كدالم لمباهن. سكالثون نسيكاي

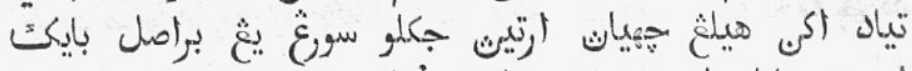

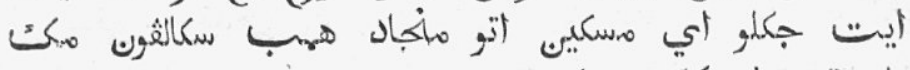

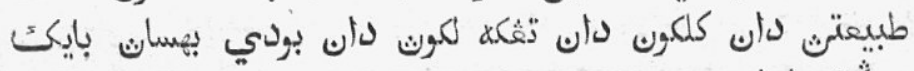

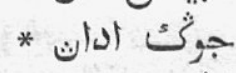

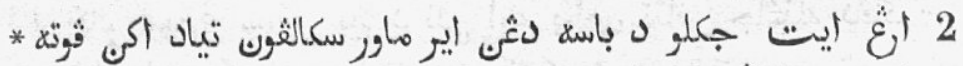

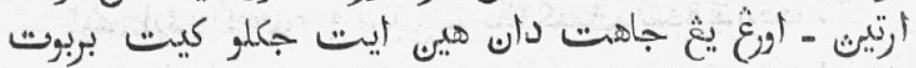

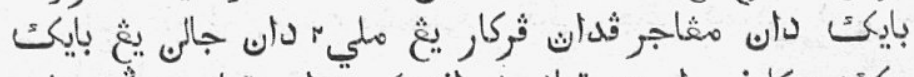

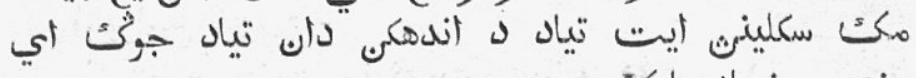
* هنات منجاد باديك

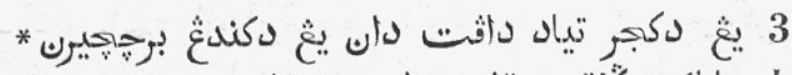

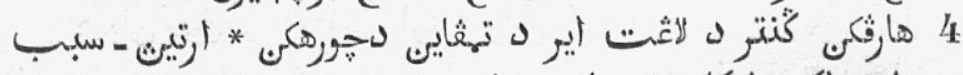

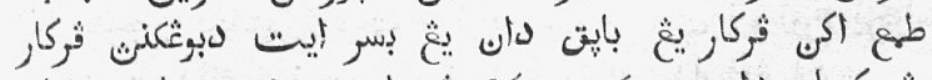

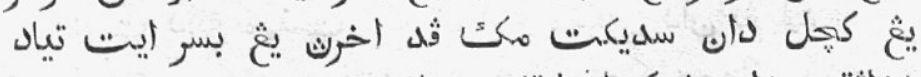

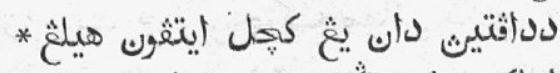

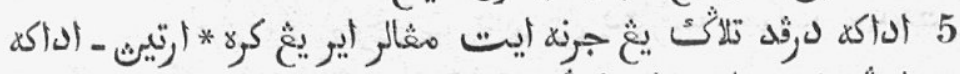

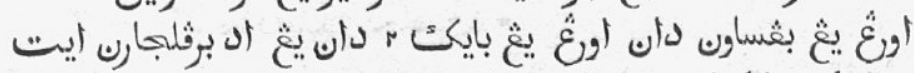

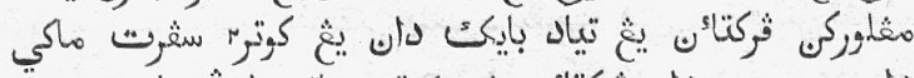

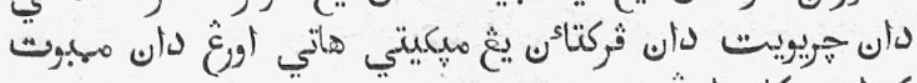

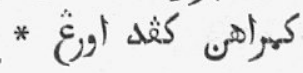


6 قانس ستاهن دهافسكن اوله هوجن سهاري * ارتيث - كبايكن.

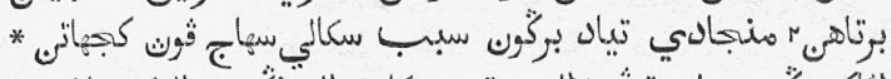

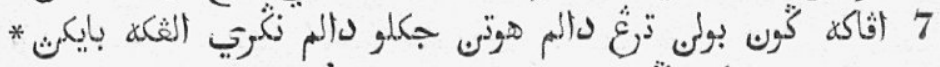

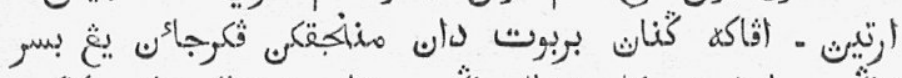

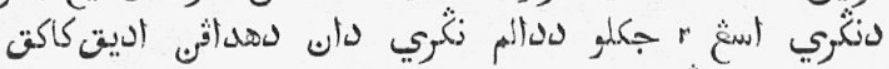

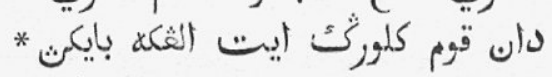

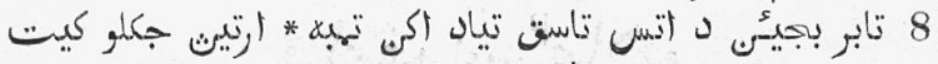

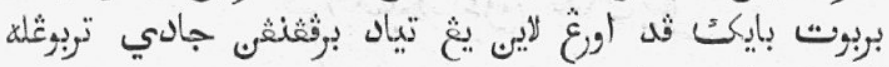

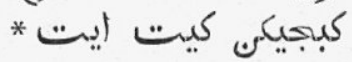

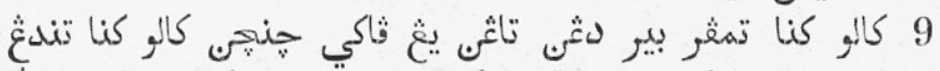

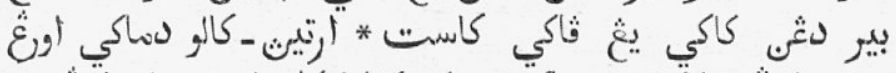

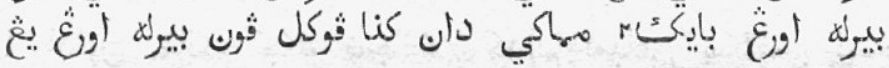

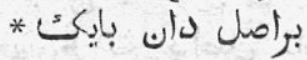
10

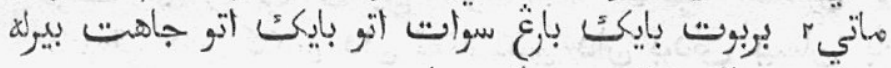

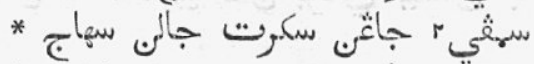

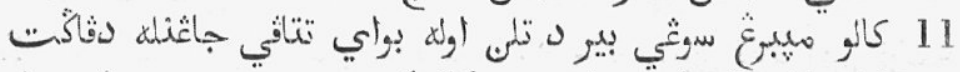

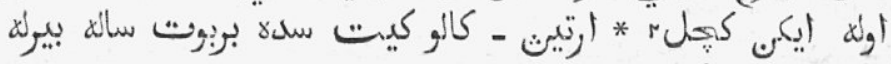

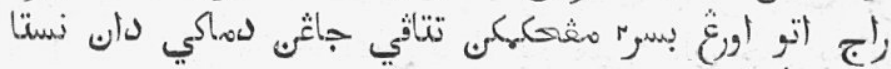

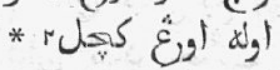

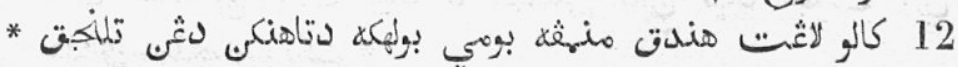

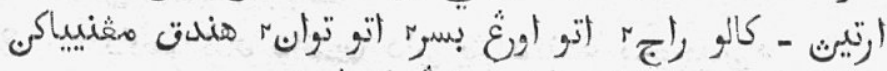

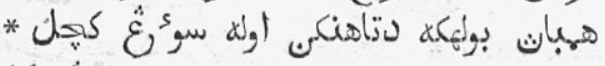

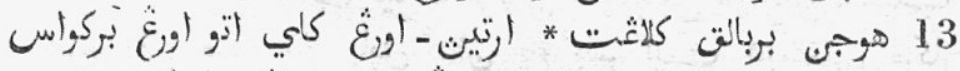

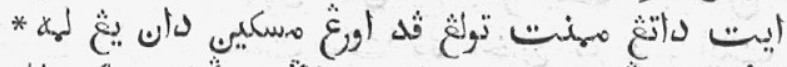

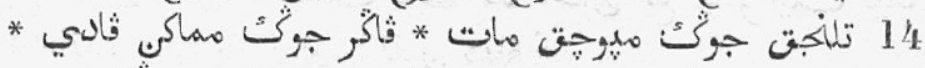

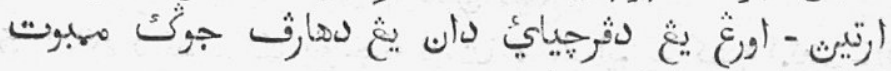

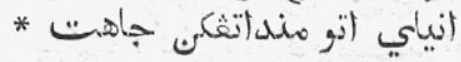
15

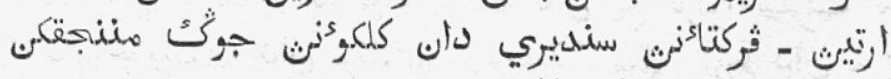

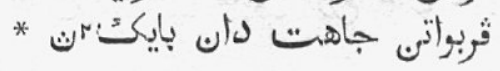




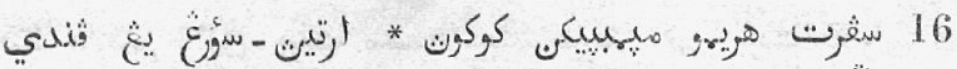

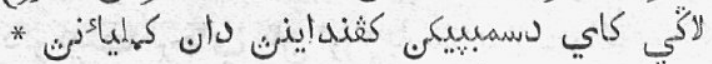

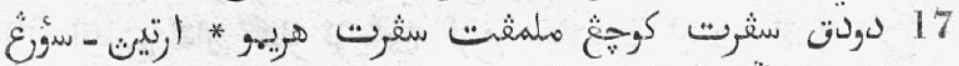

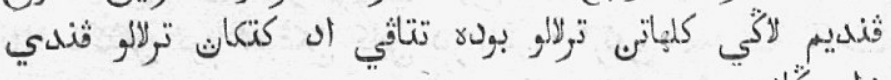

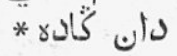

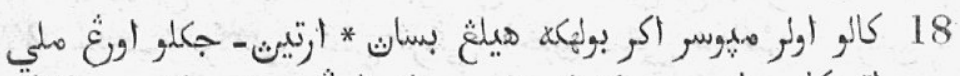

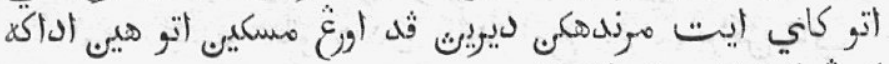

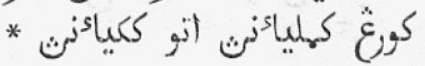

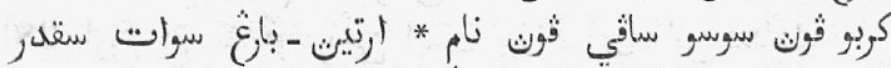

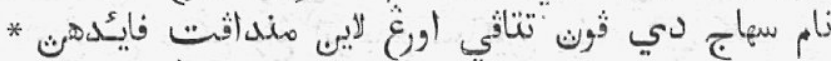

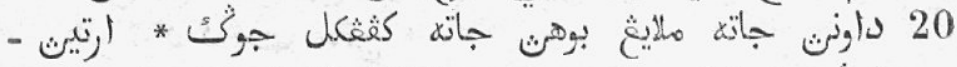

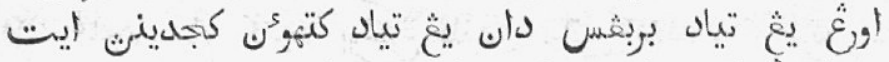

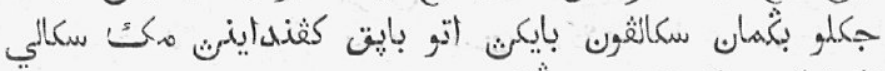

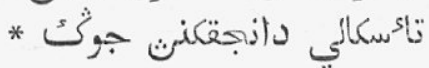

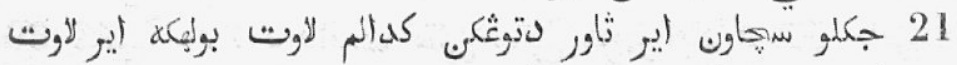

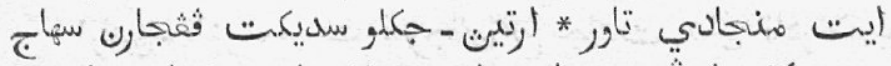

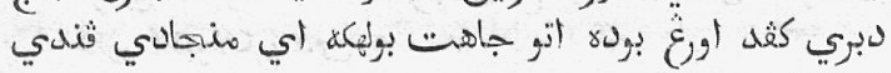

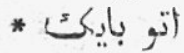

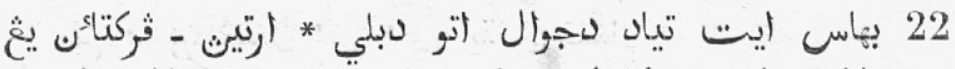

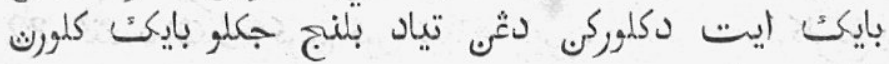

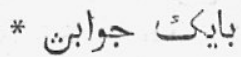

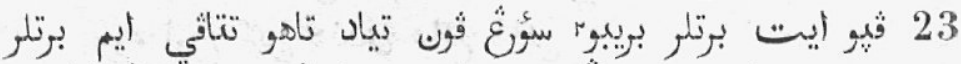

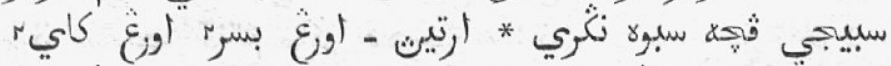

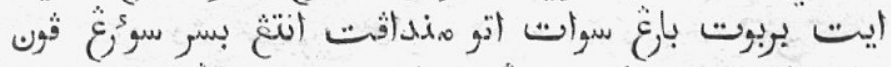

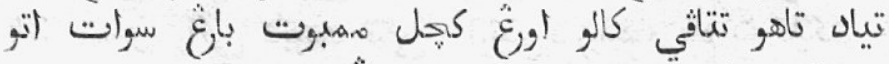

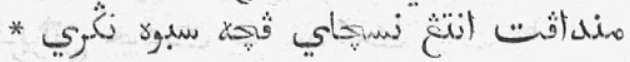

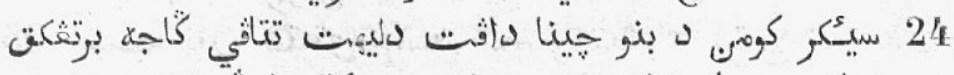

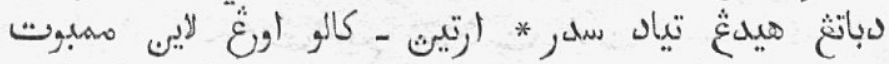

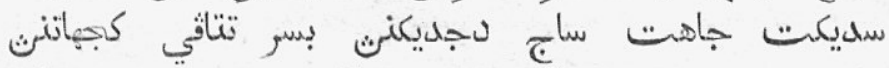

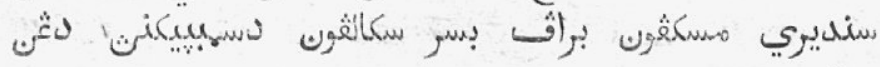

* ثrodrom 


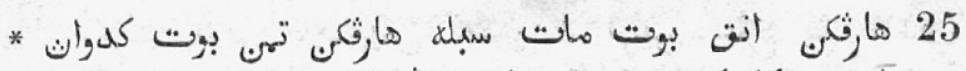

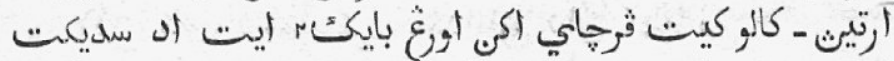

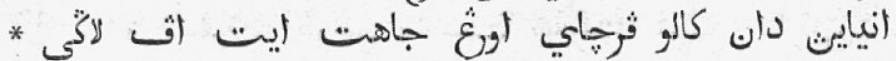

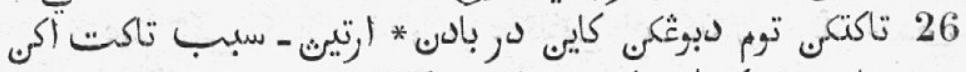

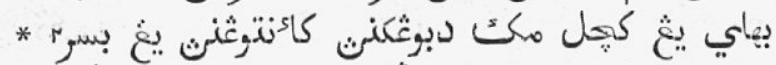

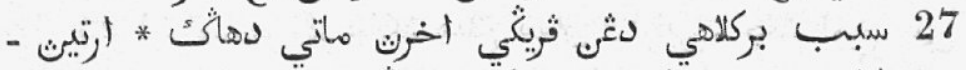

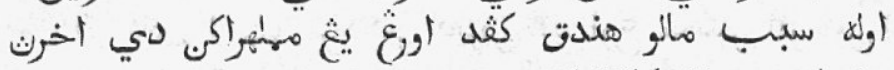

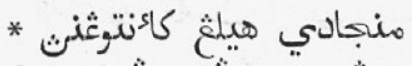

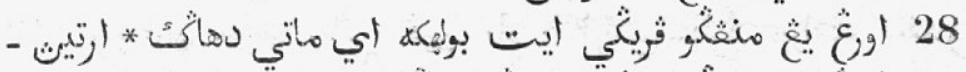

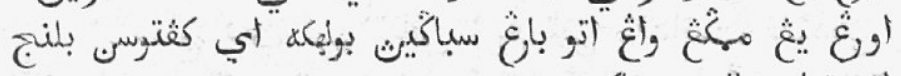

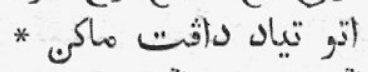

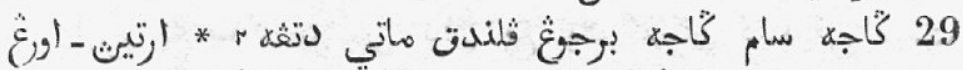

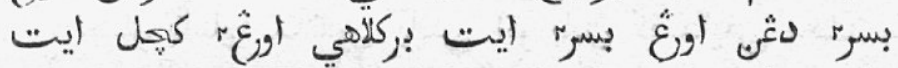

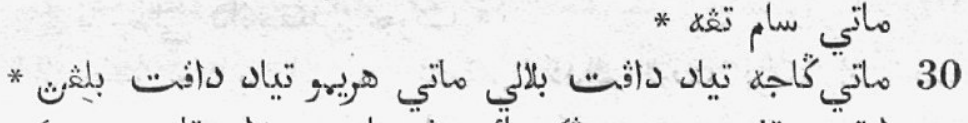

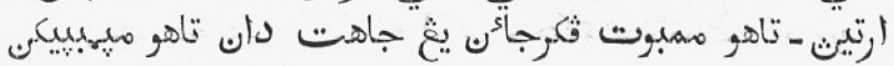

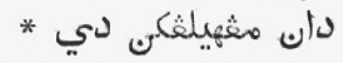

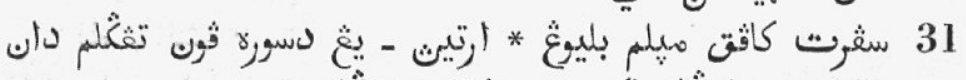

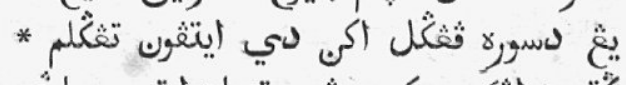
32

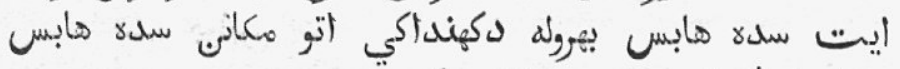

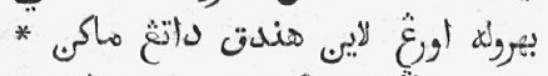

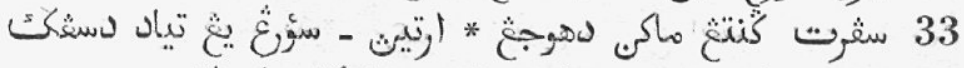

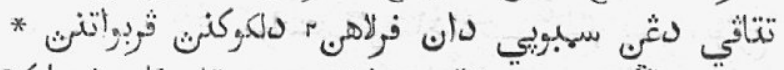

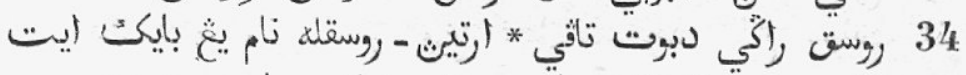

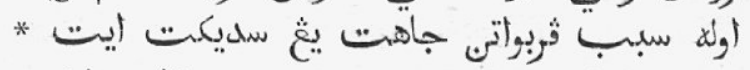

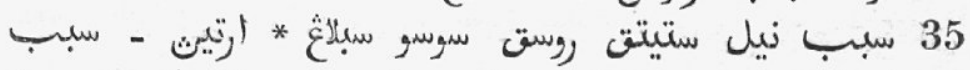

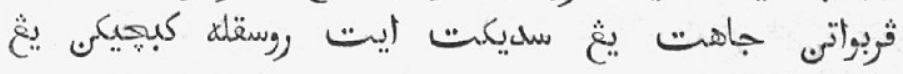
* بايتن ايت تريت

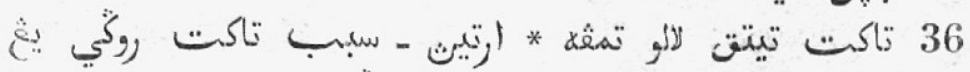

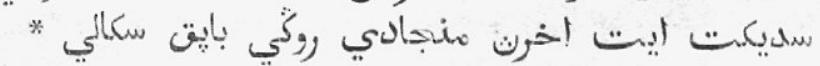


37

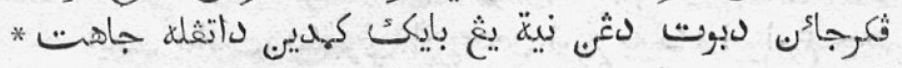

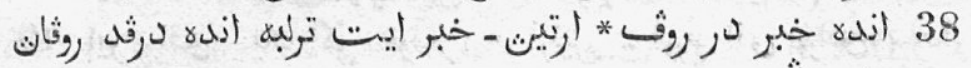

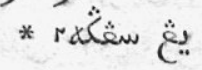

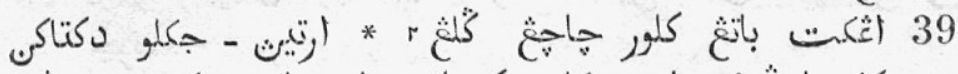

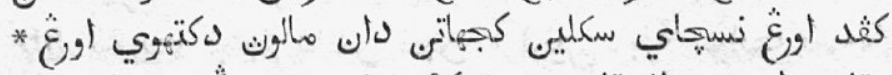

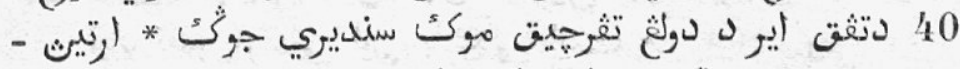

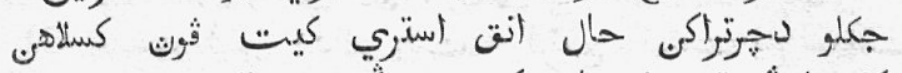

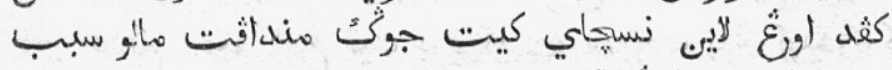

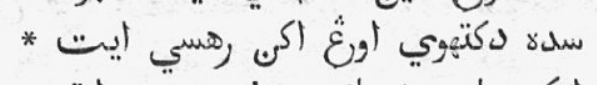
41

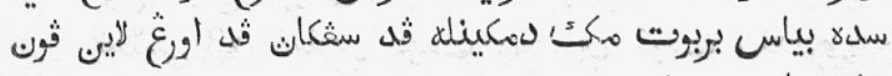

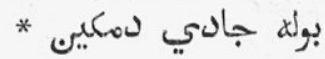

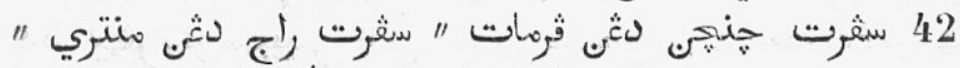

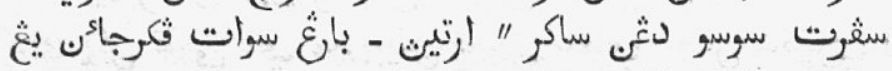

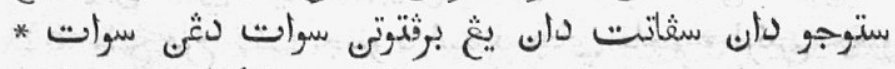

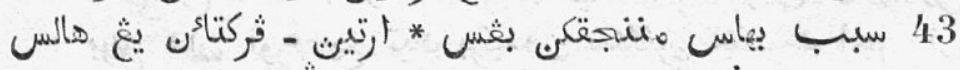

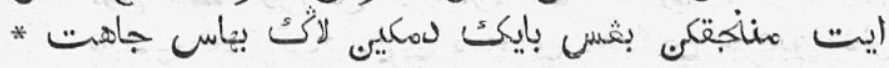

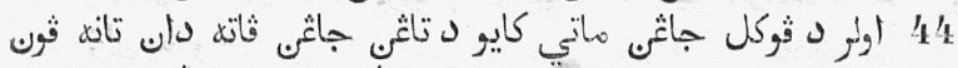

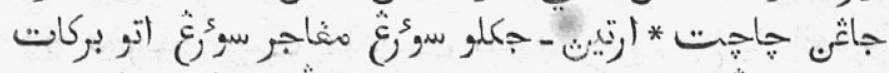

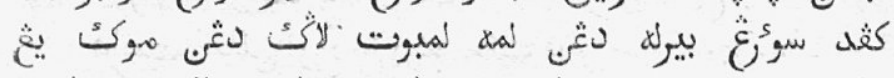

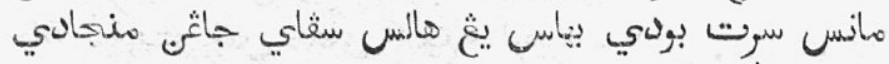

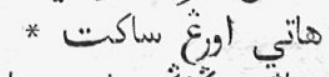

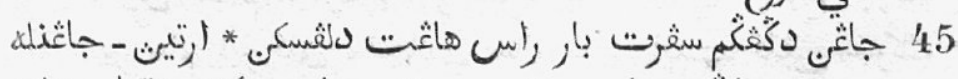

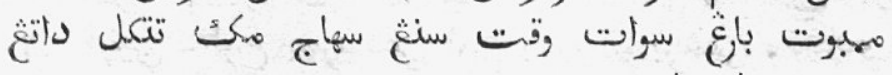
* سوسيث تياد مار

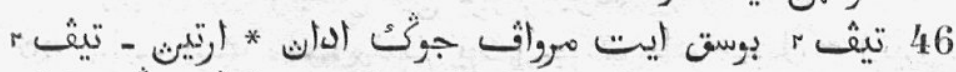

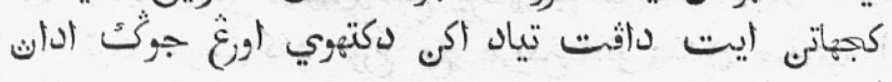
*

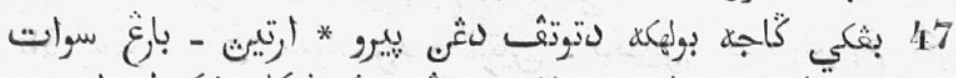

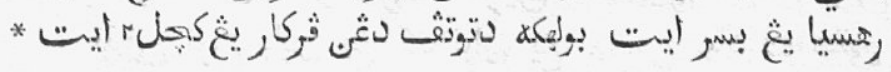




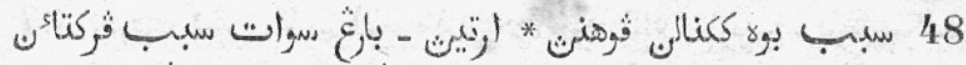

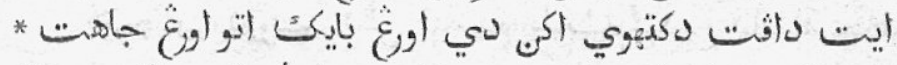

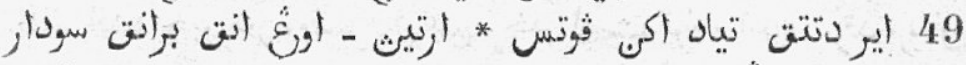

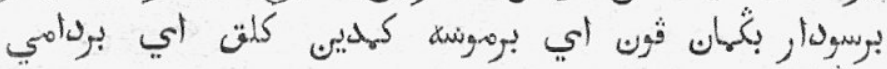

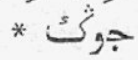

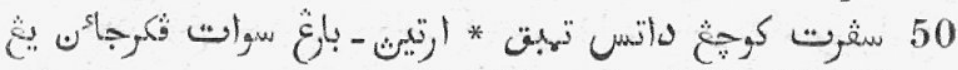

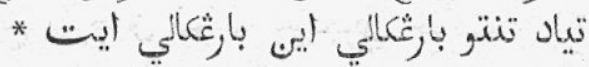

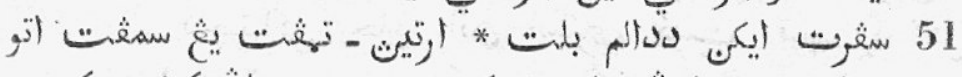

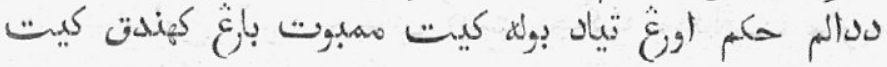
* سنديري

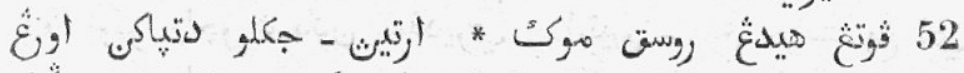

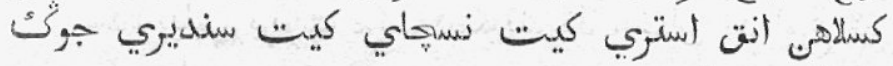

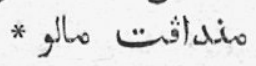

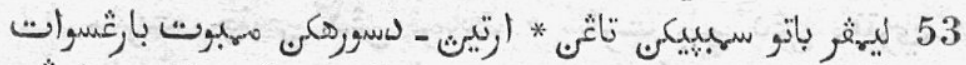

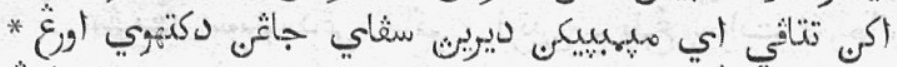

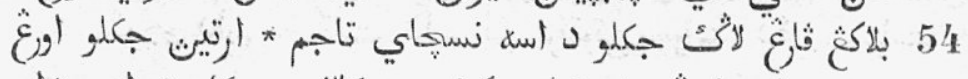

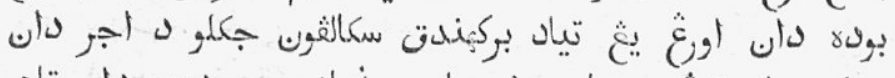

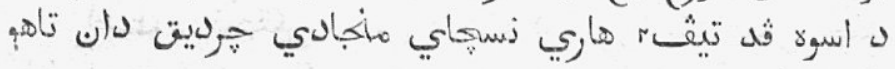
*

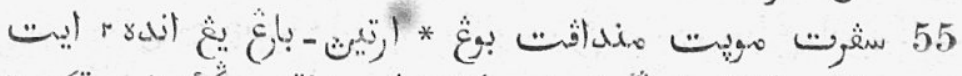

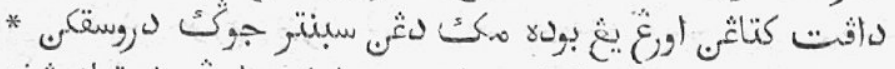

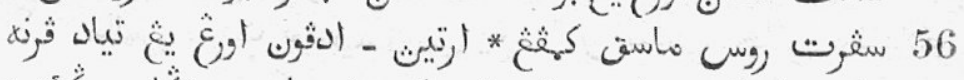

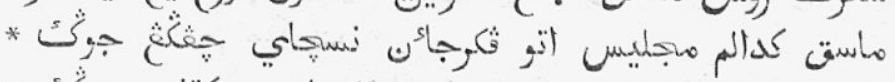

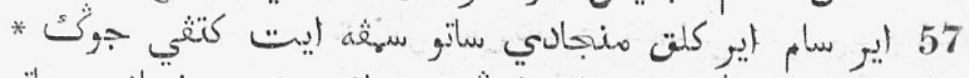

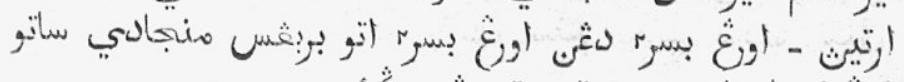

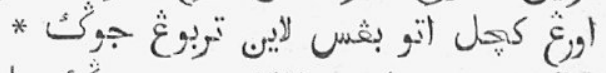

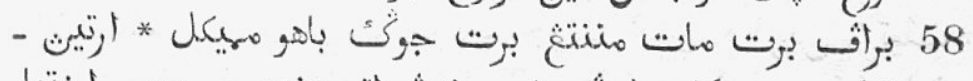

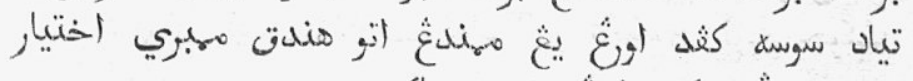

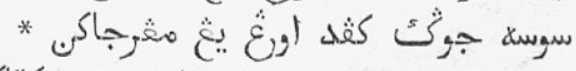

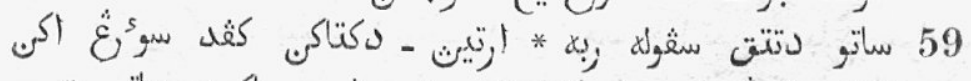

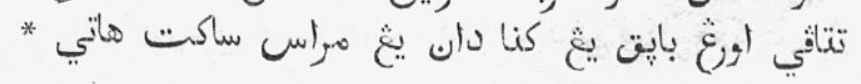


60

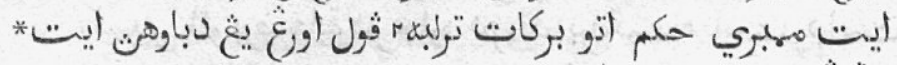

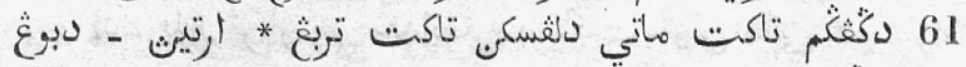

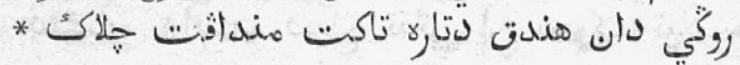

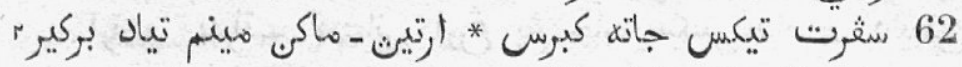

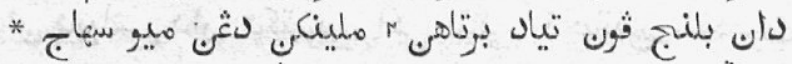

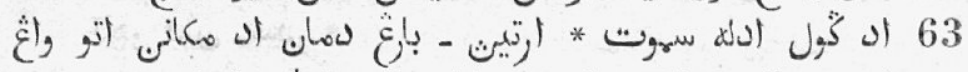

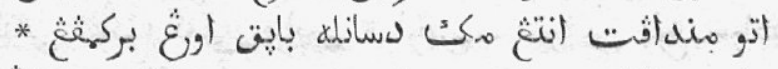

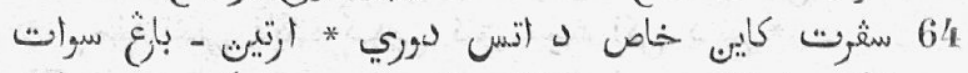

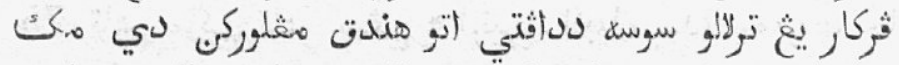

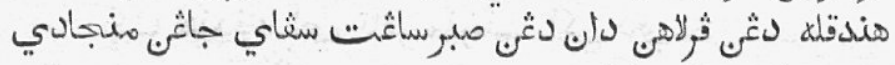

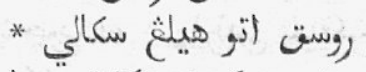

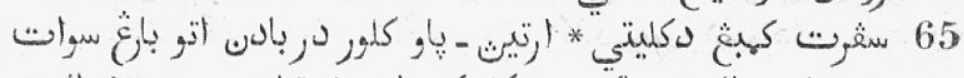

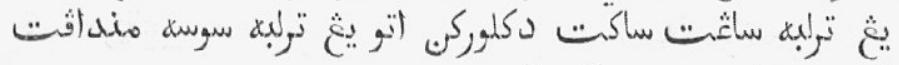

$$
\text { * اتو يث ترلبه سوسه دكرجاكئ }
$$

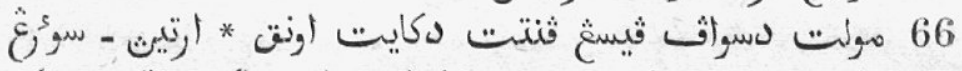

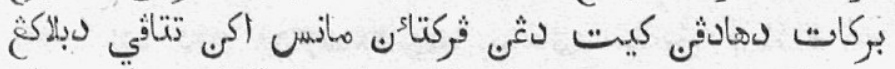

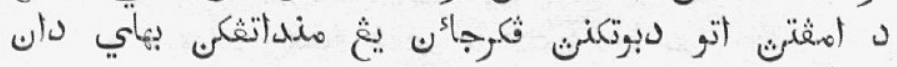
* سباكئث

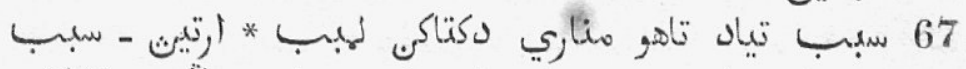

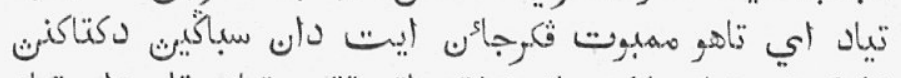

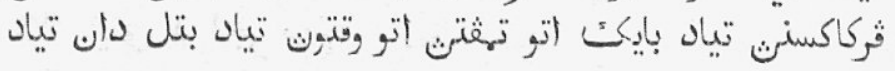
* بائيك

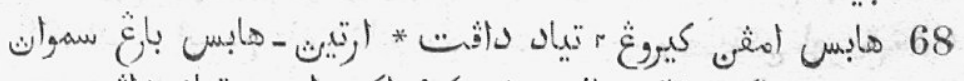

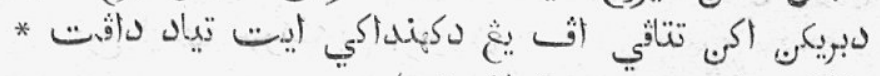

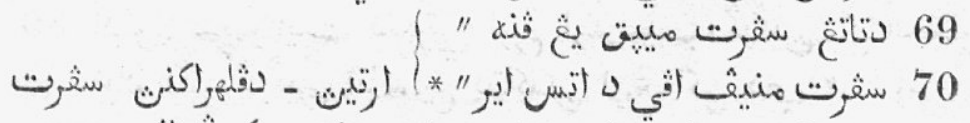

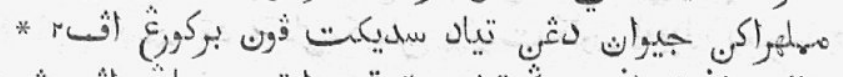
71

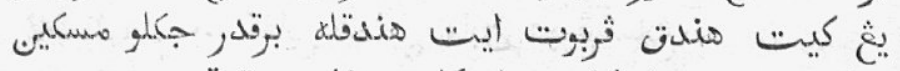

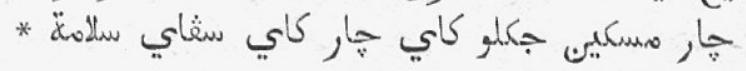




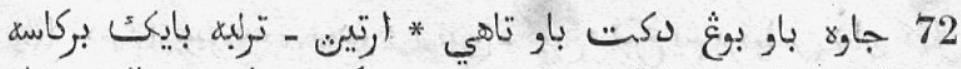

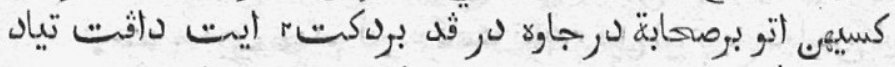

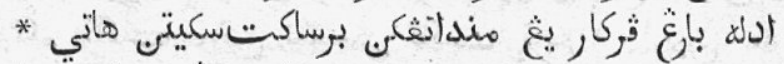

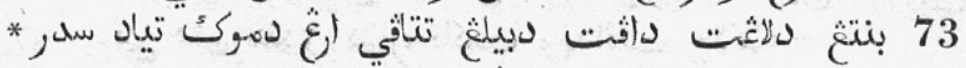

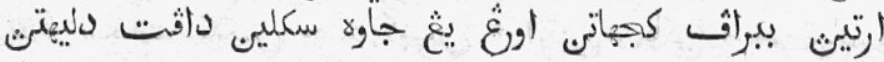

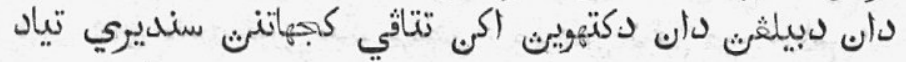

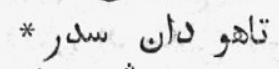

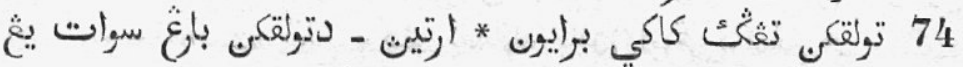

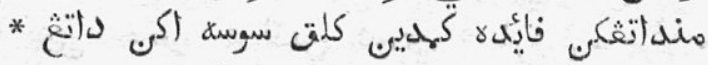

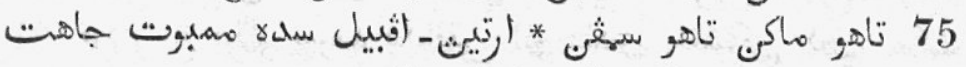

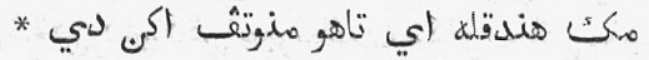

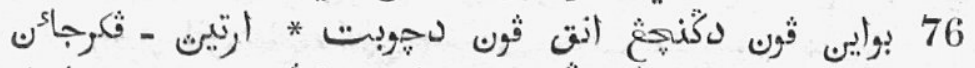

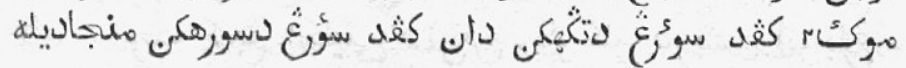
*بركانهي

$$
77 \text { ايتق د اجر برنغ توكن }
$$

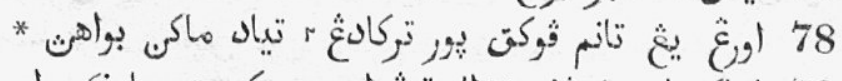

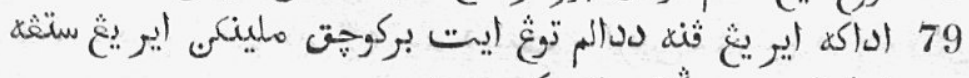

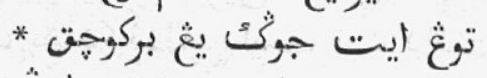

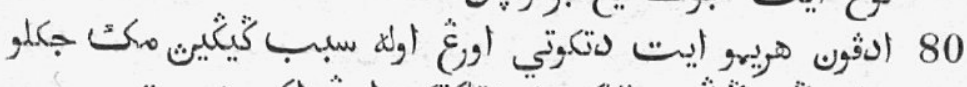

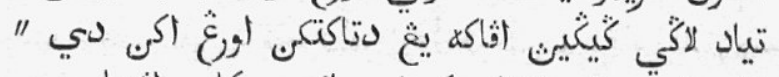

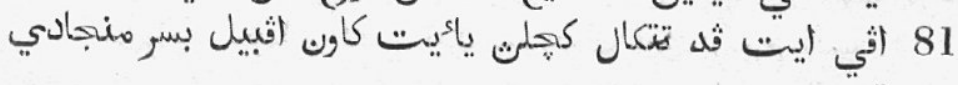

$$
\text { لاوت "الي إيت }
$$

82 ( 83

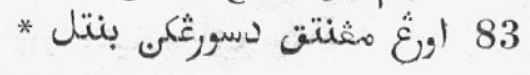


* 84 85 86 * 85 * 87 88 89

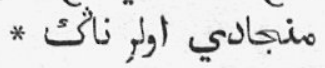

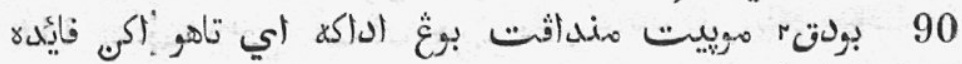
* بوغ إيت 91 * كربو جوركت

92 93 * 94 95 96

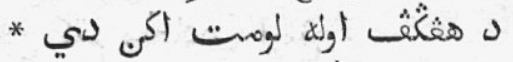
* 97 * 98 * 99 * 100 101 102

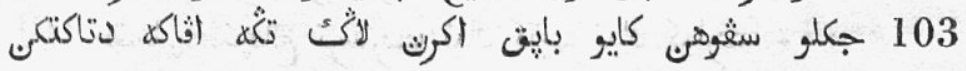
* ريبتر

104 * 105

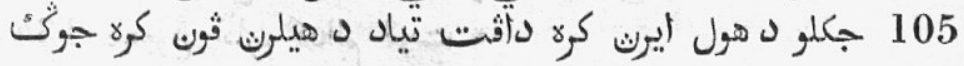
* الثالث 106

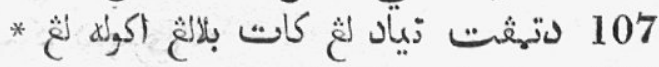

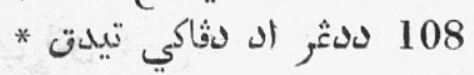




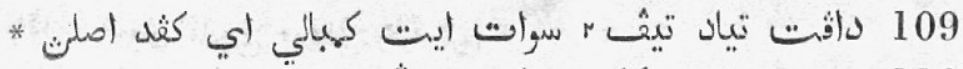

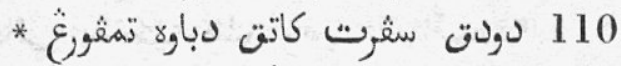

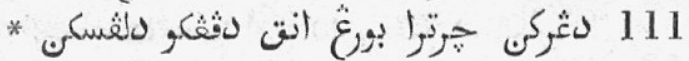
* 112 113 * 114 * 115 * 116

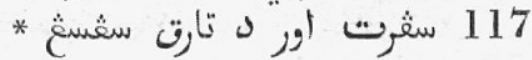

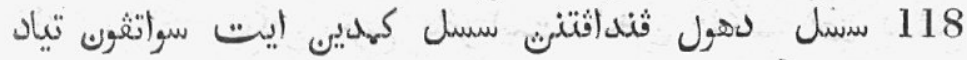

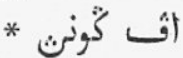

* 119

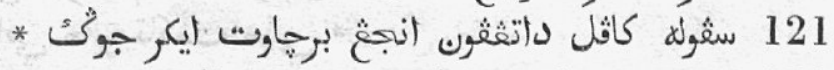
* 122 * 123 r 124 * 125 126 قلندقله لثاكث جرت 125 * 127

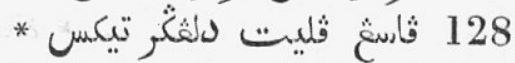

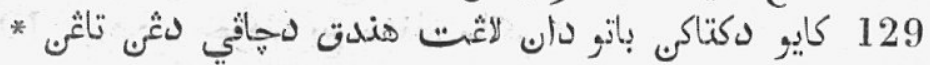
130

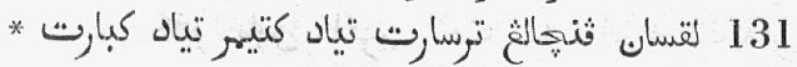
132 133 * 134 * 135 * 136 * 137

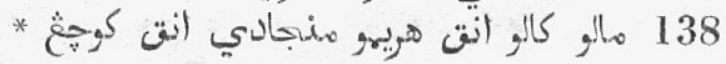




$$
\text { * } 139
$$

* 140 * 141

* 142 * 143 144 * 145

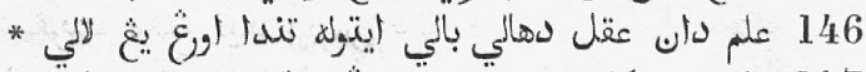

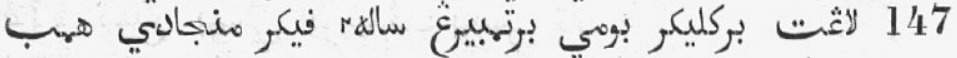

$$
\begin{aligned}
& \text { * غ }
\end{aligned}
$$

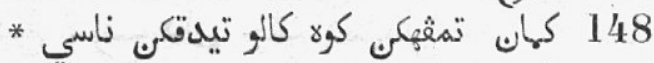

$$
\begin{aligned}
& 149 \\
& \text { * } 150
\end{aligned}
$$

151

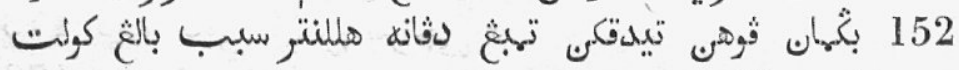

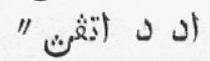

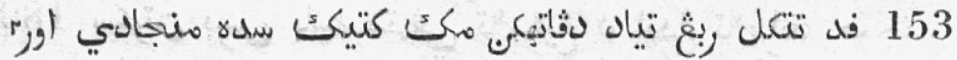
*

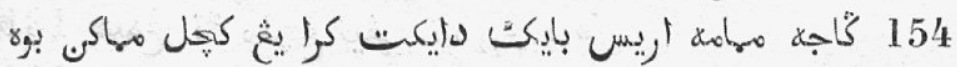
* كايو

155 * 156 157 سثرت ثورق دنليك 158 * 158

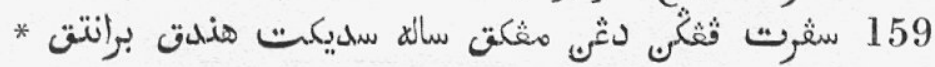
* 160 * 161 162

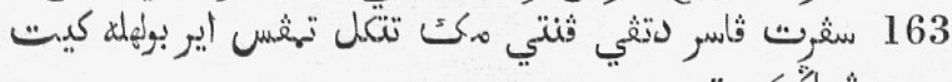
" ثرباكيّك.

* 164 
MALEISCHE SPREEKWOORDEN EN SPREEKWIJZEN.

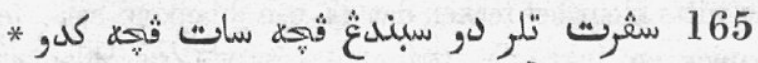

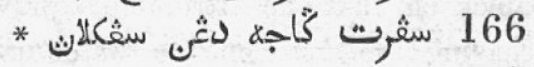

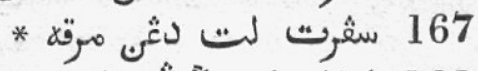

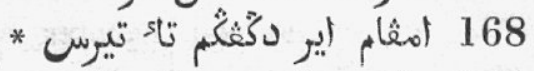

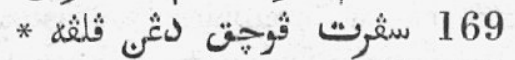

170 * Sogtend

* 171

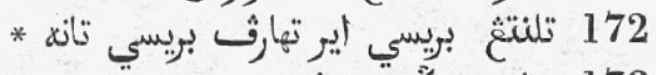

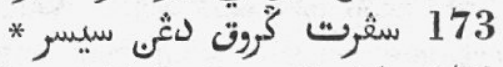

* 174

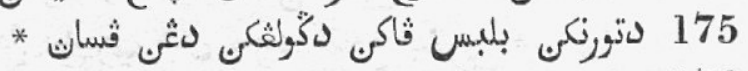

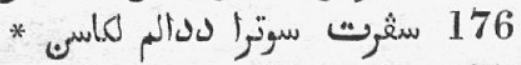

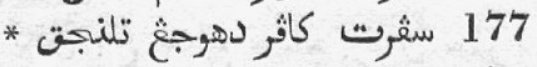

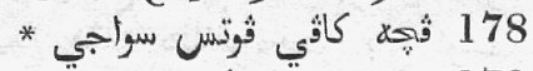

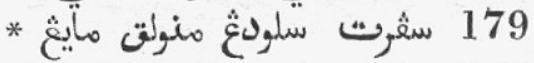

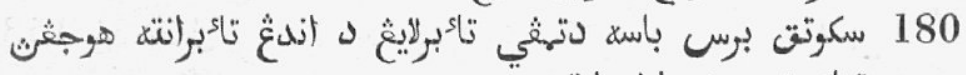

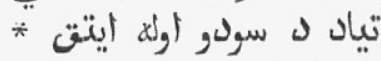

* r 181

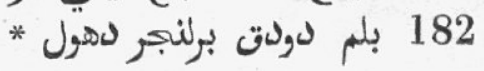


E E N I G E

\section{MALEISCHE SPREEKWOORDEN}

E N

\section{SPREEK WIJZEN,}

VERZAMELD, VERTAALD EN OPGEHELDERD

DOOR

H. C. KLINKERT. 


\title{
EENIGE OPHELDERINGEN
}

\author{
OMTRENT DE
}

MALEISCHE SPREEKWOORDEN EN SPREEKWIJZEN.

Het Maleisch schijnt aan spreekwoorden minder rijk te zijn dan het Javaansch. Vele handschriften kan men doorlezen zonder één enkel te ontmoeten. Met vele Maleijers kan men over allerlei onderwerpen hebben gesproken, zonder ook maar één uit humnen mond te hebben vernomen.

Meermalen heb ik er hun opzettelijk naar gevraagd, doch na veel bedenkens bragten zij het niet verder dan tot de mededeeling van twee of drie, die van zeer algemeene bekendheid waren en die ik daardoor reeds sedert lang in mijne verzameling had opgenomen.

Nogtans geloof ik dat er buiten de hier opgegeven nog een groot aantal onder hen schuilt, doch die men alleen zou kunnen te weten komen door meerdere bekendheid met hunne minnedichten (pantons) en door dikwerf getuige te zijn van hunne scherts. Beide hebben zij niet, of zeer zelden voor den Europeaan veil. Over den inhoud hunner minnedichten schamen zij zich voor ons te veel, dan dat zij ons die gereedelijk in handen zouden geven, en zij zijn in onze tegenwoordigheid te ernstig, te bedaard, om tot gekscheren over te gaan, al ware het dan ook slechts met elkander. De bewering echter dat de Maleijers hunne pantons niet in schrift zouden brengen en die als beurtzang slechts ex tempore voordragen, is bezijden de waarheid. De meeste zijn van vroegeren oorsprong, daar de priesters het opstellen daarvan, als strijdig met het ware geloof, thans tegengaan. Vooral de vrouwen houden zich met het overschrijven daarvan bezig, en geen Maleijer kan ze zingen, tenzij hij ze, of vooraf uit 't hoofd geleerd of ze in schrift voor zich heeft. 
De hier medegedeelde spreekwoorden heb ik gedeeltelijk uit de werken van Abdoellah bin Abdoel Kadir Moensji, voornamelijk uit zijne Hikajat Abdoellah en zijne Pělajaran, die ook om het menigvuldig en juist gebruik van spreekwoorden boven andere Maleische schriften zijn te schatten. ${ }^{1}$ Andere heb ik uit een paar pantons; sommige, maar dat waren witte raven, ook uit den mond der Maleijers en uit andere Hikajats opgeteekend. Vele heb ik ook verkregen door de vriendelijke hulp van den Eerw. heer B. F. Keasberry te Singapoera, een man, die van zijne jeugd tot zijne grijsheid de Maleijers en hunne taal heeft bestudeerd, en het voorregt heeft gehad van bovengenoemden Abdoellah tot zijn leermeester en adsistent te hebben. ${ }^{2}$

De verklaringen, bij de eerste zes en zeventig spreekwoorden opgegeven, zijn afkomstig van een kundigen Maleijer te Singapoera. $\mathrm{Bij}_{\mathrm{j}}$ de overige heb ik geen verklaring in het Maleisch gevoegd, omdat ik het werk van Maleijers niet met het mijne wilde vermengen. Wat ik dus hier in arabisch letterschrift heb gegeven is alleen van hen afkomstig.

Eerst had ik het plan gevormd om door een Maleijer van het eiland Pĕnjëngat, den zetel des onderkonings van Riouw, die

1 Buiten de beide opgenoemde werken bestaat van denzelfden schrijver nog eene vertaling van de Pantja Tandrân, een indisch fabelboek, onder den Mal. titel Hikajat Kalilah dan Daminah. Dit zijn dus geen twee verschillende werken, maar wel verschillende titels voor hetzelfde werk. Het is tijdens zijn leven te Singapoera gedrukt, doch geheel uitverkocht. Verder: Sjä̈r dari hal Singapoera lërbakar; Hikajat pada mënjatakěn pri hal doenia sěrla kaüdaännja děngan sĕgala isinja; Kilab parla měnjalakèn dari hal djĕnis djënis ilmoe kapandeijan orang Eropah en Hikajat doenia ïa itoe pada mënjatakèn dari hal běnoea Asia dan Afrika sërla dènyan toekoeng toekoeng poelaoe di tanah Malajoe. De drie laatste geheel of gedeeltelijk uit het Eng. vertaald en te Singapoera gedrukt met arabisch karakter.

${ }^{2}$ Abdoellah is reeds eenige jaren dood. Hij werd te Měkah, terwijl hij als bedevaartganger daar was en zich ook naar Konstantinopel wilde begeven, hoogst waarschijnlijk vergiftigd, omdat hij de aanteekeningen omtrent zijne reis aldaar op 't papier stelde, ondanks zulks te Měkah is verboden. Zijn zoon bragt die papieren mede naar Singapoera, waar zij in 'tbezit zijn van den heer Keasberry. 
verklaringen te laten opstellen, doch hen, die ik hier ken, acht ik onbekwaam dit naar eisch te doen. Zij zouden mij, aan zich zelven overgelaten, menige scheve verklaring hebben gegeven, daar zij op verre na niet al de hier opgegeven spreekwoorden kennen. Ook zouden stijl en spelling door mij veel hebben moeten verbeterd worden, zoodat ik zoodoende toch bijna mijne eigene verklaringen in het Maleisch zou hebben geleverd, wat ik om zoo even genoemde reden opzettelijk nalaat.

Ik moet erkennen dat de verzameling, vergeleken met die der Javaansche spreekwoorden, niet groot is, doch daarom toch niet onbelangrijk, al loopt er ook menige bloote zegswijze onder. Spreekwoorden vooral doen het karakter van taal en volk in vele bijzonderheden kennen, zoodat elke kleine bijdrage op dat gebied op goedkeuring kan hopen. Daarbij is mij niet bewust, dat er ooit eene verzameling van Maleische spreekwoorden is uitgegeven. Dwaal ik hierin, dan wijte men zulks aan mijn verblijf in Indie, waar men niet dan zeer moeijelijk op de hoogte kan blijven van alles wat op wetenschappelijk gebied in het licht komt.

Met de openbaring van dit weinige heb ik echter nog een bijzonder doel. Ik veronderstel namelijk dat zij, die meer en langer dan ik het Maleisch hebben beoefend, deze verzameling met menig, mij en anderen onbekend spreekwoord zullen kunnen aanvullen. Daartoe wilde ik hen uitlokken, opdat de Maleische taalstudie niet ten achteren blijve bij de beoefening van het Javaansch, dat in de laatste jaren wel wat te uitsluitend den voorrang heeft genoten. ${ }^{1}$

Ik geef hierbij een transcriptie en de vertaling benevens de verklaring van die spreekwoorden, die daarvan niet in het Maleisch zijn voorzien, naar aanleiding van hetgeen mij door mijn maleischen schrijver daaromtrent is medegedeeld. Ik doe dit om misverstand te voorkomen, daar men in Europa dikwerf dwaalt in de spelling, uitspraak en beteekenis der woorden. Is het hier reeds moeijelijk menig woord goed te verstaan, hoeveel te meer daar, waar men zich niet of hoogst zelden tot een Maleijer om inlichting kan wenden. Dit is dan ook de reden waarom in Maleische woordenboeken, zamengesteld in Europa, bij nog zoo hooggeroemde voorlichting, zulk eene menigte fouten voorkomt, dat de correctie alleen reeds een boekdeel zou ver-

${ }^{1}$ Op het punt dit naąr Europa te zenden verneem ik; dat de heer Von Dewall, wien ik mijn voornemen had medegedeeld, daardoor is aangespoord, om ook eene verzameling van Mal. spreek woorden te maken. 
eischen lijviger dan zulk een woordenboek. Daarenboven kan men zich eenigzins voorstellen hoe mager de inhoud van die woordenboeken zijn moet, als men bedenkt, dat hij voor 't grootste gedeelte bestaat uit woorden, die men in enkele ten dienste staande handschriften en in gebrekkige en verouderde lexica heeft gevonden. En hoe weinig handelen die H. S. nog over de zaken des dagelijkschen levens. Meestal zijn het sprookjes, handelende over goden en geesten, vorsten en helden, prinsen en princessen, die reizen, bovennatuurlijke daden verrigten en dit met eten, drinken en mingenot afwisselen. Werken van eenigzins degelijken inhoud zijn weinig in getal.

Men noemt de Maleische taal arm, en zij is het ook, doch niet zoo als men zich dikwerf voorstelt, vooral niet wat haren woordenschat betreft. Dat zij ons voor afgetrokken begrippen vele malen geen woord kan aanbieden, heeft ze met alle talen van den Indischen Archipel, of liever van alle volken, die nog niet tot de hoogte van onze christelijke beschaving en ontwikkeling zijn opgeklommen, gemeen, maar men beoordeele toch vooral haren rijkdom of hare armoede niet naar de bestaande woordenboeken of den inhoud der gekende handschriften. Wanneer de Maleijers met elkander op de balei-balei zitten te keuvelen over allerlei onderwerpen uit het dagelijksche leven, zijn zij om geen woorden verlegen, en die gesprekken zouden, indien ze werden opgeteekend, onze bestaande woordenboeken vrij wat bijvoegsels, vermeerderingen, verbeteringen en aanhangsels verschaffen. De verzameling van spreekwoorden, die ik hier geef, kan daarvoor ten bewijze strekken.

Wat de spelling van het Maleisch geschreven met arabisch karakter aangaat, moet ik verschooning vragen voor de enkele fouten, die, tegen mijn wil daarin zijn geslopen. Eenmaal afgeschreven is het arabische schrift zeer moeijelijk te corrigeren. Ik hoop hierbij op de vriendelijke hulp van hem, die zich met de correctie der drukproeven zal willen belasten. De fout, die eenige malen terugkeert, is het verkeerde gebruik van de 1 de, en de , waaraan de Maleijers zich altijd schuldig maken, hoe men zich daartegen ook verzet. ${ }^{1}$

Bij de transcriptie heb ik zoo weinig mogelijk vreemde teekens

${ }^{1}$ Aan dit verzoek is slechts ten deele door mij voldaan, daar het gebruik der genoemde letters zelfs in gesloten lettergrepen duidelijkheidshalve geschiedt.

I) corrector. 
gebruikt, mij alleen tot de noodzakelijkste bepaald en mij door geen stelsels van anderen laten binden.

Hopende met deze verzameling iets te hebben bijgedragen tot de kennis eener zoo liefelijke taal, het Italiaansch van den Indischen Archipel, en tevreden met het nut en genoegen dat ze mij heeft verschaft, beveel ik haar in de welwillende belangstelling der beoefenaren van het Maleisch aan.

Riouw, 15 Februarij 1865.

H. C. Kinnkert.

\section{TRANSCRIPTIE EN VERTALING.}

1. Adapon manikam itoe djikalaoe di djatohkěn kadalam lembahan sa'kalipon nisljaja tiada akan hilang tjahjanja. Al laat men een juweel ook in een modderpoel vallen, zijn glans gaat zeker niet verloren.

Artinja: djikalaoe sa'orang jang běrasal baik itoe djikalaoe ia mëskin alaw mëndjadi hamba sa'kalipon maka tabiatnja dan kalakoewan dan tingkah lakoenja dan boedi bahasanja baik djoega adanja.

Beteekenis: al wordt iemand van goede afkomst ook arm of een dienstknecht, zoo blijven zijn inborst en gedrag en benemingen en manieren toch goed.

2. Arang iloe djikalaoe di basoh déngan aĕr mawar sa'kalipon tiada akan poetih.

Houtskool, al wordt zij ook met rozewater gewasschen, zal niet wit worden.

Artinja: orang jang djahat dan hina itoe djikalaoe kita bërboewat baik dan mëngadjar padanja perkara jang moelia moelia dan djalan jang baik, maka sakaliannja itoe tiada di indahkën dan tiada djoega ia hëndak mëndjadi baik. Beteekenis: een slecht en laag mensch, al doen wij hem goed en leeren hem kostelijke dingen en den goeden weg, zal dit alles niet achten noch goed willen worden.

3. Jang di këdjar tiada dapat dan jang di kandoeng bërtjèljèran.

Het nagejaagde niet krijgen en wat gedragen wordt stort hier en daar bij beetjes uit. (Vrij vert. Wat men najaagt niet verkrijgen en wat men heeft intusschen verliezen.)

4. Haraplièn goentoer di langil aër di lampajan di tjoerahkèn. 
Hopende op donder uit den hemel, het water uit het aarden vat gieten.

Artinja: sebab tama' akan përkara jang banjak dan jang běsar itoe di boewangkěnnja pěrkara jang kěljil dan sa'dikit maka pada achirnja jang bessar itoe tiada di dapatinja dan jang kětjil itoepon hilang.

Beteekenis: door begeerte naar vele en groote dingen wordt door hem het kleine en weinige weg geworpen; zoo vindt hij ten laatste het groote niet, en gaat het kleine ook verloren.

5. Adakah daripada tělaga jang djěrnih itoe mëngalir aĕr jang kèroeh?

Vloeit er wel troebel water uit een helder meer?

Artinja: adakah orang jang bangsawan dan orang baikbaik dan jang běrpěladjaran itoe měngěloewarkěn pěrkataän jang tiada baik dan jang kotor-kotor sapěrti maki dan tjěrěwet ${ }^{1}$ dan pěrkataün jang mënjakiti hati orang dan měmboewat kamarahan kapada orang?

Beteekenis: Uit iemand van goede afkomst, een geschikt en wel onderwezen mensch, ooit slechte en vuile woorden, zoo als schelden en gesnater en woorden die iemands gemoed ergeren of hem toornig maken?

6. Panas satahoen di hapoestien oleh hoerjan sahari.

De hitte van een jaar wordt weggevaagd door den regen van een dag.

Artinja: kabuikan běrtahoen-tahoen měndjadi tiada bĕrgoena sĕbab sakali sahadju poenja karljahatan.

Beteekenis: de goede werken van vele jaren worden onnut door slechts ééne wandaad (lett. door de ondeugd van slechts ééne keer.)

7. Apakah goena boelan těrang di dalam hoetan dijikalaoe di dalam nagri alangkah baiknja.

Wat nut het als de maan in 't bosch schijnt, zoo 't in de stad ware hoeveel beter zou dit zijn?

Artinja: apakah goenanja běrboewat dan. měnoendjoekkèn pakèrdjaän jang běsar di nagri asing-asing djikalaoe di dalam nagri dan di hadapan adik kakak dan kaoem kaloewarga itoe alangkah baiknja?

Beteekenis: wat nut het groote werken te doen en te toonen in

1 Volgens het Maleisch schrift (zie bl. 39) zoude de uitspraak moeten zijn tjërèwèt.

Corrector. 
vreemde landen? Indien men zulks in eigen land en voor broeders en zusters en verwanten deed, hoeveel beter zou dat zijn!

8. Taboer bidjian di atas tasik tiada akan toemboeh.

Zaad op een meer gestrooid zal niet opkomen.

Artinja: djikalaoe kita berrboewat baik pada orang lain jang tiada bĕrpěngěnangan mëndjadi tĕrboewanglah kabëdjikan kita itoe.

Beteekenis : Als wij goed doen aan anderen die er niet mede gediend zijn, dan worden onze weldaden als weg geworpen.

9. Kalaoe kěna tampar biar děngan tangan pakei tjintjin; kalaoe kěna těndang biar dëngan kaki jang pakei kasoet. Als men een klap in 't aangezigt krijgt, laat het met een hand zijn, waaraan een ring is; als men getrapt wordt, laat het wezen met een voet, die een schoen aan heeft.

Artinja: kalaoe di maki orang, biarlah orang baik-baik měmaki, dan kěna poekoel pon biarlah orang jang bërasal dan baik. Beteekenis: als men gescholden wordt, laat het een behoorlijk mensch zijn, die scheldt, en als men slaag krijgt, laat het dan ook wezen van een voornaam en goed persoon.

10. Mati-mati mandi biar basah; mati-mati berdawat biarlah hitam.

Als men goed (of tot verzadiging toe) heeft gebaad, laat men dan nat zijn, en als men genoegzaam inkt heeft gebruikt, laat het dan zwart wezen.

Artinja: mati-mati bĕrboewat baik barang soeatoe, ataw baik ataw djahat, biarlah sampei-sampei, djangan sa'kĕrat djalan saharlja.

Beteekenis : het een of ander goeds geheel en al doen, hetzij goed, hetzij kwaad, laat het ten volle zijn, niet slechts een stukje van den weg.

11. Kalaoe mënjëbrang soengei, biar di tělan oleh boewaja, tělapi djanganlah di pagoet oleh ikan kětjïl-këtjil.

Als men eene rivier doorwaadt, laat men dan door een krokodil ingeslikt, maar niet door de kleine visschen (het vleesch van 't lijf) gebeten worden.

Artinja: kalaoe kita soedah bërboewat salah, biarlah radja alaw orang běsar-běsar mënghoekoemkĕn, tětapi djangan di maki dan di nista oleh orang kětjil-kětjil.

Beteekenis: als we eene fout begaan hebben, laat de vorst of de aanzienlijken ons oordeelen, maar laat ons niet door den geringen man worden gescholden en verguisd. 
12. Kalaoe langit hëndak mĕnimpah boemi, bolehkal di tahan$k$ ěn děngan těloendjoek?

Als de hemel op aarde wil vallen, kan hij door een' wijsvinger worden tegengehouden?

Artinja: kalaoe radja-radja ataw orang běsar-bĕsar hĕndak mënganiajakěn hambanja, bolehkah di tahankĕn oleh sa'orang kètjil?

Beteekenis: als vorsten of grooten of heeren hunne dienaren willen onderdrukken, kan de kleine man dat weerhouden?

13. IIoedjan berbalik kalangit.

De regen keert weer naar den hemel.

Artinja: orang kaja alaw orang bĕrkoewasa itoe datěng mëminta toeloeng pada orang měskin dan jang lěmah.

Beteekenis: een rijke en magtige komt hulp vragen bij een arme en zwakke.

14. Těloendjoek djoega mĕnjoetjoek mata; pagar djoega mĕmakan padi.

Zelfs de wijsvinger steekt oogen uit; zelfs de heiming eet rijst.

Artinja: orang jang di pertjajai dan jang di harap djoega mëmboewat aniaja ataw měndatěngkěn iljahat.

Beteekenis: zelfs de mensch, dien men vertrouwt en op wien men hoopt, verdrukt en brengt onheil aan.

15. Saperti harimaoe měnoendjoekkěn bělangnja; sapěrti doerian mënoendjoekkĕn pangsanja.

Gelijk een tijger zijne vlekken vertoont, gelijk eene doerianvrucht hare vakken laat zien.

Aanm. Men kan aan den buitenkant der doerian-vrucht aan hare naden zien war de vakken inwendig zich van elkander scheiden.

Artinja: pěrkataännja sěndiri dan kalakoewannja djoega mënoendjoekkěn përboewatan djahat dan baik-baiknja.

Beteekenis : zijne eigene woorden en ook zijne gedragingen toonen zijne slechte en goede daden.

16. Sapěrti harimaoe ménjěmboenjikěn koekoenja.

Gelijk een tijger zijne nagels verbergt.

Artinja: sa'orang jang pandei, lagi kaja, di sěmboenjikèn kapandeijannja dan kamoetiä̈nja.

Beteekenis: een kundig en rijk man zijne kunde en uitnemendheid verbergende.

17. Doedoek sapěrti koet.jing; mëlompat sapěrti harimaoe. 
Zitten als eene kat; springen als een tijger.

Artinja: sa'orang pěndiam, lagi kalihatan tërlaloe bodoh, tětapi ada koetikanja tërlaloe pandei dan gadoeh.

Beteekenis : een zwijger, die bovendien er zeer dom uitziet, maar die tijden heeft waarop hij zeer knap en luidruchtig is.

18. Kalaoe oelar menjoesoer akar bolehkah hilang bisanja?

Als een slang langs een wortel strijkt, gaat daardoor zijn gif verloren?

Artinja: djikalaoe orang moelia ataw kaja itoe měrěndahkën dirinja pada orang mëskin ataw hina, adakah koerang kamoeliä̈nnja ataw kakajaänja?

Beteekenis: als een voornaam of groot man zich nederbuigt tot de armen of geringen, vermindert daardoor zijne voornaamheid of grootheid?

19. Karbaoe poenja soesoe, sapi poenja nama.

De melk is van den buffel, den naam heeft de koe.

Artinja: barang soeatoe sakědar nama salıadja dia poenja, tělapi orang lain měndapat faédahnja.

Beteekenis: van het een of ander heeft hij slechts zooveel als den naam, doch anderen hebben er het voordeel van.

20. Daoennja djatoh mělajang, boewahnja djatoh kapangkal djoega.

De bladeren vallen zwevende, de vruchten echter aan den voet van den stam.

Artinja: orang jang tiada bĕrbangsa dan jang tiada $k a-$ tahoeän kadjadiannja itoe, djikalaoe bagimana sa'kalipon baiknja ataw banjak kapandeijannja, maka sa'kali ta' sa'kali di oendjoekkěnnja djoega.

Beteekenis : iemand van geen aanzienlijk geslacht en wiens afkomst onbekend is, al is zijne goedheid ook nog zoo groot of zijn zijne kundigheden nog zoo vele, den een of anderen keer zal hij zulks toch doen blijken.

21. Djikalaoe sa'tjawan aĕr tawar di toewangkèn kadalam laoet, bolehkah aĕr laoet itoe měndjadi tawar?

Als een kopje zoet water in de zee gegoten wordt, kan de zee daardoor zoet worden?

Artinja: djikalaoe sa'dikit pëngadjaran sahadja di bĕri kapada orang bodoh ataw djahat bolehkah ia měndjadi pandei ataw baik?

Beteekenis : als slechts een weinig onderrigt gegeven wordt aan een dom of slecht mensch, kan hị daardoor wijs of goed worden? 
22. Bahasa itoe tiada di djoewal ataw di bèli.

De taal wordt niet verkocht noch gekocht.

Artinja: pěrkataän jang baik itoe di kěloewarkèn děngan tiada bělandja, djikalaoe baik kěloewarnja baiklah djawabnja.

Beteekenis: goede woorden worden zonder onkosten geuit; zoo hun naar buiten komen goed is, zal ook het wederwoord goed zijn.

23. Pěnjoe itoe běrtělor běriboe-riboe, sa'orang pon tiarla tahoe, tělapi ajam běrtělor sa'bidji, pětjah sa'boewah nagri.

De schildpad legt duizende eijeren en niemand weet het; de hen legt er slechts één en 't wordt in heel eene stad bekend (letterl. geheel eene stad breekt er van).

Artinja: orang běsar-běsar ataw orang kaja-kaja itoe běrboewat barang soeatoe ataw měndapat oentoeng běsar, sa'orang pon tiada tahoe, tëtapi kalaoe orang kětijit měmboevoat barang soeatoe alaw méndapat oentoeng, nixijaja pét.jah sa'boewah nagri.

Beteekenis: als de grooten en aanzienlijken wat doeñ of groot voordeel behalen, weet niemand er iets van, mar als de kleine man iets verrigt of een gelukje heeft dan wordt het door geheel eene stad bekend.

24. Sa'ekoer koemoen ${ }^{1}$ di bĕnoea tjïna dapat di lihat, tétapi gadjah bërtěngkek di batang hidoeng tiada ia sëdar.

Een insektje in het land van China kan hij zien, maar een olifant, op zijn neusbeen zittende. wordt hij niet gewaar. Artinja: kalaoe orang lain mëmboewat sa'dikit djahat sahadja di djadikěnnja běsar, tětapi kadjahatannja sěndiri, maskipon běrapa běsar sakalipon, di sěmboenjikénnja déngan sa'boleh-bolehnja.

Beteekenis: als andere slechts een weinig kwaads verrigten maakt hij het groot, maar zijn eigen kwaad, al is 't ook nog zoo groot, wordt door hem zooveel mogelijk verborgen.

25. Harapkèn anak, boeta mata sa'bëlah; harapkěn těman, boeta karloevoanja.

Vertrouwen op een kind is blindheid aan één oog; vertrouwen op een kameraad is blindheid aan beide.

Artinja: kalaoe kita pertjaja akan orang baik-baik itoe ada sa'dlikit aniajanja, dan kalaoe pěrtjaja orang djahat itoe apa lagi?

1 In No. 142 is de transcriptie kooman.

Corrector. 
MALEISCHE SPREEKWOORDEN EN SPREEKWIJZEN.

Beteekenis: als wij vertrouwen op een goed mensch, zoo is er eenig leed bij, hoeveel te meer als we op een ondeugd ous vertrouwen stellen.

26. Takoetkèn toema di boewangkèn kain dari badan. Uit vrees voor luizen het kleed van 't lijf werpen. Arlinja: sěbab takoet akan bahaja jang kètjil maka di boewangkènnja kaoentoengannja jang běsar-běsar itoe.

Beteekeuis: uit vrees voor een klein onheil wordt door hen zijn groot geluk verworpen.

27. Sěbab běrkalahi děngan pĕrigi achirnja mati dahaga. Door met den put te twisten ten laatste van dorst sterven. Artinja: oleh sěbab maloe hëndak toendoek kapada orang jang mëměliharakèn dia, achirja mendjadi hilang kaoentoengannja.

Beteekenis: door niet te willen buigen voor den man die hen onderhoudt, gaat ten laatste zijn voordeel verloren.

28. Orang jang mĕnoenggoe pěrigi itoe bolehkah ia mati dahaga?

Kan hij, die den put bewaakt, wel van dorst sterven? Artinja: orang jang mëmĕgang wang ataw barang sa'bageinja, bolehkah ia kapoetoesan bělandja ataw tiada dapat makan?

Beteekenis : kan hij, die geld of iets dergelijks beheert, wel ten einde geld geraken of niet te eten krijgen?

29. G'arljah sama gadjah bërdjoewang, pělandoek mati di těngah-tëngali.

De eene olifant vecht met den ander, het dwerghert sterft in hun midden.

Ariinja: orang bĕsar-běsar děngan orang bĕsar-běsar itoe bërkalahi, orang-orang kětjil itoe mati sama těngah.

Beteekenis: de grooten twisten met de grooten, de kleine man sterft in hun midden.

30. Mati gadjah tiada dupat boelalei, mati harimaoe tiada dapat bělangnja.

De olifant sterft en de snuit wordt niet gevonden; de tijger sterft en zijne vlekken vindt men niet.

Artinja: tahoe mĕmboewat pakěrdjaän jang djahat dan tahoe mënjëmboenjikèn dan mënghilangkën dia.

Beteekenis: het kwade weten te doen en het weten te verbergen of te doen verdwijnen.

31. Sapërti kapak mënjëlain balioeng. 
Gelijk een bijl duikt naar een dissel.

Artinja: jang di soeroeh pon těnggělam dan jang di soeroeh panggil akan dia itoepon těnggělam.

Beteekenis : en die vitgezonden is blijft weg, en die gestuurd wordt hem te roepen komt ook niet weer boven water. (letterl. die uitgezonden is zinkt en die gestuurd wordt om hem te roepen zinkt ook).

32. Gëlah di angkat koeran pon tiba.

Aanmerking. Met alle mogelijke navraag is het mij hier nog niet gelukt de beteekenis der woorden gětah en koeran te weten te komen. Ik heb dit spreekwoord letterlijk overgeschreven, hoewel ik veronderstel, dat het eerste woord fout gespeld is en L' géta, een soort van zetel of zitbank voor aanzienlijken, moet wezen. Maleijers van Pënjëngat, door mij geraadpleegd, houden kveran voor een of ander gereedschap uit de huishouding, maar konden niet zeggen welk. Zij veronderstellen dat dit spreekwoord van de oostkust van het Maleisch Schiereiland afkomstig is en het woord koeran daar wel zou worden verstaan. Ik ben niet in de gelegenheid de waarheid van die bewering te onderzoeken. Is hunne veronderstelling gegrond dan zou de vertaling zijn: Bij het wegnemen van de ritbank komt de koeran (een zeker gereedschap? dat zoek was) voor den dag. Artinja: barang soeatoe pěrkara jang bërgoena itoe soedah habis, baharoelah di kahěndaki orang, ataw makanan soedah habis, baharoelah orang lain hëndak datěng makan. Beteekenis: de een of andere nuttige zaak is afgeloopen, dan krijgt men pas begeerte daarnaar; of: het eten is op, dan pas wil een ander koinen eten.

33. Sapěrti goenting makan di hoedjoèng

Gelijk de schaar snijdt aan de punten.

Artinja: sa'orang jang tiada di sangka, tětapi děngan sěmboenji-sěmboenji dan pěrlahan di lakoekěnnja pěrboewatannja.

Beteekenis : iemand, van wien het niet gedacht wordt, maar die (toch) stilletjes en langzaam zijne daden verrigt.

34. Roesak ragi di boewat tapei.

De gist bederft als er tapei van gemaakt wordt.

Aanmerking. De zin van dit spreekwoord is moeijelijk zonder omschrijving terug te geven. Tapei is eene versnapering, die bereid wordt uit kleefrijst (poeloet) door die eerst boven 
den wasem van heet water te gaan koken, nadat ze is bekoeld met gist te vermengen, dan in kleine hoeveelheden ter grootte van een mondvol te verdeelen, elk deel afzonderlijk in pisang-blad te wikkelen en zoo droog in eene pot gedurende twee etmalen te laten gisten. Deze tapei heeft dan een zoeten wijnsmaak en is, even als het vocht, dat zich daaruit heeft afgescheiden eenigzins bedwelmend. De kleur van dit vocht is als die van witte brandewijn. De bereiding moet met de grootste omzigtigheid geschieden; want één droppeltje regenwater of één korreltje zout of de onzuivere adem van de bereidster doet de gisting totaal mislukken. Met deze in alle deelen juiste opgave gelieve men te vergelijken de verklaringen, die in de Maleische woordenboeken van tapei worden gegeven en men zal verbaasd staan over de onjuistheid en onvolledigheid daarvan. Zooals dit spreekwoord hier is opgegeven is het min verstaanbaar. Duidelijker zou het zijn (en dit is ook geheel de bedoeling) als er stond: Sapěrti roesak ragi tatkala di boewat tapei. Hiervoor pleit zeer de opgave der beteekenis in het Maleisch, die hier volgt:

Arlinja: roesaklah nama jang baik itoe oleh sěbab perboewatan djahat jang sa'dikit itoe.

Beteekenis: een goede naam bederft door een weinig slechte daden.

35. Sěbab nila sa'titik roesak soesoe sa'bělanga.

Door één droppel indigo bederft een geheele pot met melk. Artinja: sěbab përboewatan djahat jang sa'dikit itoe roesaklah kabědjikan jang banjak-banjak itoe.

Beteekenis: door een weinig slechte daden bederven vele goede werken.

36. Takoet titik laloe toempah.

Uit vrees voor spatten overgaan tot storten.

Artinja: sëbab takoet roegi jang sa'dikit itoe achirnja mëndjadi roegi banjuk sa'kali.

Beteekenis: uit vrees, voor een weinig verlies wordt ten laatste zeer veel nadeel geboren.

37. Di boewat dèngan karěna Allah mëndjadi moerka Allah. Gedaan om Godswil verwekt Gods toorn. Artinja: barang soeatoe pakèrdjaän di boewat déngan niat jang baik, kamoedian datěnglah djahat.

Beteekenis: het een of ander werk wordt met goede bedoeling verrigt, doch daarna komt er kwaad uit voort. 


\section{Indah chabar dari roepa.}

De tijding is schooner dan de gedaante.

Artinja: chabar itoe těrlěbeh indah daripada roepanja jang soenggoeh soenggoeh.

Beteekenis: het gerucht is schooner dan de wezenlijke gedaante er van.

39. Angkat batang kěloewar tjatjing gělang-gělang.

Ligt de rottende boomstam op en de aardwormen komen voor den dag.

Artinja: djakalaoe di katakèn kapada orang nistjaja sa'kalian kadjahatannja dan maloenja di kětahoez̈ orang.

Beteekenis: als het iemand gezegd wordt dan weet men voorzeker al zijne ondeugden en zijne schande.

Aanmerking. Deze zin is niet zeer duidelijk, doch de bedoeling van den schrijver kan men gemakkelijk raden.

40. Di těpok aĕr di doelang tëpěrtjik moeka sĕndiri djoega.

Wordt het water in een houten schotel geklopt dan wordt (des kloppers) eigen aangezigt ook bespat.

Artinja: djikalaoe di tjaritčrakèn hal anak istri kita poenja kasalahan kapada orang lain, nistjaja kita djoega mĕndapat maloe, sěbab soedah di kětahoë̈ orang akan rahasia itoe.

Beteekenis : als de fouten van onze vrouw en kinderen worder verteld aan anderen, dan krijgen wij voorzeker ook schande, door dat men die (onze) geheimen weet.

41. Oekoer badjoe di badan sěndiri.

Het baadje (en niet baaitje zoo als Siegenbeek en Weiland verkeerdelijk opgeven) meten aan eigen lijf.

Arinija: barang soeatoe jang ia soedah biasa bèrboewat maka dèmkianlah pada sangkanja pada orang lain pon boleh djadi dëmkian.

Beteekenis : het een of ander, dat hij gewoon is te verrigten, denkt hij dat juist zóó ook bij anderen kan geschieden.

42. Sa'pěrti tjintjin děngan pěrmata;

Sa'pěrti radja děngan mantri;

Sa'pěrti soesoe děngan sakar;

Gelijk de ring met het juweel.

Gelijk de vorst met de ministers.

Gelijk melk met suiker.

Artinja: barang soeatoe pakèrdjaän jang sa'toedjoe dan sa'patoet dan jang bërpatoetan soeatoe děngan soeatoe. 
MALEISCHE SPREEKWOORDEN EN SPREEKWIJZEN.

Beteekenis: eenig werk, waarvan het eene met het andere overeenkomt en overeenstemt en het eene bij het andere behoort.

43. Š̌bab bahasa měnoendjoekkèn bangsa.

Aan de taal kent men het volk.

Artinja: pěrkatä̈n jang haloes itoe mënoendjoekkën bangsa baik, děmkian lagi bahasa djahat.

Beteekenis: beschaafde woorden duiden goed volk aan, zoo ook slechte taal (het tegenovergestelde).

44. Oelar di poekoel, djangan mati; kajoe di tangan djangan patah dan tanah pon tjatjat djangan.

Wordt de slang geslagen, laat het niet zijn ten doode; laat het hout in de hand niet breken en laat ook de grond geene gebreken hebben.

Aanm. Deze vertaling is volgens mijn schrijver. $\mathrm{lk}$ zou liever vertalen: laat de grond niet besmet wezen, nam. met het bloed van den slang.

Artinja: djikalaoe sa'orang měngadjar akan sa'orang ataw běrkata kapada sa'orang, biarlah děngan lěmah lěmboet, lagi děngan moeka jang manis sěrta boedi bahasa jang haloes, sopaja djangan mëndjadi hati orang sakit.

Beteekenis: indien men iemand onderwijst of met iemand spreekt, laat het met zachtheid en met een vriẻndelijk gelaat en fijne manieren geschieden, opdat iemands hart niet verbitterd worde.

45. Djangan di gěngam sapěrti bara, rasa hangat di lěpaskěn.

Laat het niet in de vuist gehouden worden als eene kool vuurs, bij 't voelen der warmte wordt het los gelaten.

Artinja: djanganlah mëmboewat barang soeatoe waktoe sěnang saharlja, maka tatkala datěng soesahnja tiada maoe. Beteekenis: doe niet het een of ander alleen bij eene goede gelegenheid en als de moeijelijkheden komen dan niet willen.

46. Tiap-tiap boesoek mërěwap djoega adanja.

Elke bedorvene zaak wasemt ook uit (doet haren stank opstijgen).

Artinja: tiap-tiap kadjahatan itoe dapat tiada akan di kětahoei orang djoega adanja lambat laoen.

Beteekenis : het kan niet missen of elk bijzonder kwaad zal ten langen laatste door de menschen geweten worden.

47. Bangkei gadjah bolekkah di toetoep déngan njiroe?

IX (XIII). 
Kan ook het kreng eens olifants bedekt worden met eene rijstwan?

Artinja: barang soeatoe rahasia jang bessar itoe bolehkah di toetoep děngan pěrkara jang kětjil-kětjil itoe?

Beteekenis : kan ook het een of ander groote geheim bedekt worden met kleine zaken?

48. Sěbab boewah kakènalan pohonnja.

Aan de vrucht wordt de boom gekend.

Artinja: barang soeatoe sěbab pěrkatä̈n itoe dapat di kětahoeï akan dia orang baik ataw orang djahat.

Beteekenis: (In) een of ander aan de woorden kan het ten opzigte van hem geweten worden (of hij) een goed of slecht mensch is.

49. Aěr di tětak tiada akan poetoes.

Water, gehouwen wordende, zal niet breken.

Artinja: orang anak běranak ataw saoedara běrsaoeılara bagimanapon ia běrmoesoeh kěmoedian kělak ia běrdamei djoega.

Beteekenis : hoe ook ouders en kinderen of broeders en zusters elkander vijandig zijn, daarna zullen zij weder vrede maken.

50. Sa'pěrti koetjing di atas tèmbok.

Als eene kat op den muur.

Artinja: barang soeatoe pakěrdjaän jang tiada těntoe barangkali ini, barangkali itoe.

Beteekenis: het een of ander werk, dat niet zeker is, mogelijk dit, mogelijk dat.

Aanm. De zin van dit spreekwoord is minder duidelijk opgegeven. Het is ontleend aan de wijze waarop eene kat op een muur zit, alsof zij in onzekerheid verkeerde wat te doen en daarover in alle deftigheid nadenkt. Bij haar wordt een mensch vergeleken van wien wij zeggen: hij zit met zijne ziel onder den arm.

51. Sa'pěrti ikan dalam bělat.

Als een visch in een fuik.

Artinja: dalam těmpat jang soempit ataw dalam hoekoem orang tiada boleh kita mëmboewat barang kahěndak kita sendiri.

Beteekenis : in eene bekrompene plaats of onder het gebied van menschen kunnen wij onzen wil niet ten uitvoer brengen.

52. Potong kidoeng roesak moeka. . 
(Vrij vert.) Die zijn neus schendt, schendt zijn aangezigt. Artinja: djikalaoe di njatakèn pada orang kasalahan anak istri kita, nistjaja kita sĕndiri djoega měndapat maloe. Beteekenis: als aan anderen de fouten van onze vrouw en kinderen worden geopenbaard dan krijgen wij zelf voorzeker ook schande.

53. Limpar baloe sěmboenjikèn tangan.

Met steenen gooijen en de hand verbergen.

Artinja: di soeroehtěn mĕmboevat barang soeatoe akan tětapi ia mĕnjĕmboenjikěn dirinja sopaja djangan di kětahoei orang.

Beteekenis : het een of ander wordt (door hem) bevolen te doen, maar hij verbergt zich zelven, opdat het niet door de menschen geweten worde (dat hij de bewerker is).

54. Bëlakang parang lagi djikalaoe di asah nistjaja tadjëm. Zelfs de rug van een hakmes, als hij geslepen wordt, zal zeker scherp zijn.

Artinja: djikalaoe orang bodoh dan orang jang tiada běrkahěndak sa'kalipon, djikalaoe di adjar dan di asoeh pada tiap-tiap hari, nistjaja mĕndjadi tjěrdik dan tahoe dan maoe. Beteekenis: indien een dom en zeer onwillig mensch iederen dag onderwezen en opgevoed wordt, zoo zal hij zeker bij de hand en kundig en willig worden.

55. Sapěrti monjet měndapat boenga.

Zoo als een aap die bloemen vindt.

Artinja: barang jang indah-indah itoe dapat katangan orang jang bodoh, maka děngan saběntar djoegadi roesakkěn.

Beteekenis : kostbare zaken, in handen van domme menschen gekomen, worden in één oogenblik bedorven.

56. Sapěrti roesa masolk kampoeng.

Gelijk een hert komt in eene buurt.

Artinja: adapon orang, jang tiada pěrnah masok kadalam madjëlis ataw pakěrdjaän, nistjaja tjĕngkoeng ${ }^{1}$ djoega.

Beteekenis: iemand die nooit in eene vergadering of eene betrekking is geweest zal zeker verlegen zijn (als hij pas daarin komt).

57. Aěr sama aěr kělak měndjadi satoe, sampah itoe katěpi djoega. Water met water zal spoedig één worden; het vuil (drijft) toch naar den kant.

1 De text heeft

Corrector. 
Artinja: orang běsar-bĕsar dĕngan orang bĕsar-běsar atav bĕrbangsa měndjadi satoe, orang kětjil ataw bangsa lain těrboewang djoega.

Beteekenis : grooten met grooten of aanzienlijken worden het eens, de kleine man of iemand van een ander geslacht is toch verworpen.

58. Bërapa bërat mata mënĕntang bërat djoega bahoe mĕmikoel. Hoe zwaar het oog het aanziet, zwaar inderdaad is het voor den dragenden schouder.

Artinja: tiada soesah kapada orang jang mëmandang ataw hëndak mëmběri ichtiar, soesah djoega kapada orang jang mëngěrdjakěn.

Beteekenis: ' $t$ is niet moeijelijk voor iemand, die toekijkt, of die teregtwijzingen wil geven, wèl is het moeijelijk voor hem, die het ten uitvoer brengt.

59. Satoe di tětak sa'poeloeh rěbah, Één wordt gehouwen, tien vallen om.

Artinja: di katakèn kapada sa'orang akan tëtapi orang banjak jang kěna dan jang mërasa sakit hati.

Beteekenis : tot éen mensch wordt er over gesproken, doch vele menschen worden geraakt en gevoelen ergernis.

60. Koerang-koerang boeboer, lěbih-lěbih soedoe.

Hoe minder pap, hoe meer lepels.

Artinja: koerang-koerang orang jang běrkoewasa dan kapala itoe mëmbëri hoekoem atan bërkata, těrlěbih-lěbih poela orang jang di bawahnja itoe.

Beteekenis: hoe minder magtigen en hoofden bevelen geven of spreken, zooveel te meer de lieden, die onder hen zijn.

61. Di gěnggam takoet mati, di lëpaskěn takoet tërbang.

In de vuist gehouden vreezen (dat hij) dood gaat, los gelaten vreezen (dat hij) weg vliegt.

Artinja: hëndak di boewang takoet roegi, dan hëndak di taroh takoet mĕndapat tjilaka.

Beteekenis : zoo 't weg geworpen wordt verlies vreezen en zoo 't behouden wordt vreezen een ongeluk te krijgen.

62. Sapërti tikoes djatoh kaběras.

Gelijk eene rot op de rijst valt.

Artinja: Makan minoem tiada bĕrkira-kira dan bělandja pon tiada bërtahan-tahan, mĕlainken dëngan mewa sahadja. Beteekenis : eten en drinken zonder maat, en de kosten niet kumnen dragen, behalve dit, alles slechts in overdaad. 
63. Ada goela, adalah sěmoet.

Is er suiker dan zijn er mieren.

Artinja: barang di mana ada makanan ataw wang ataw měndapat oentong, maka di sanalah banjak orang běrkampoeng.

Beteekenis : waar eten of geld is of voordeel verkregen wordt, daar vergaderen veel menschen.

64. Saperti kain chasa di atas doeri.

Gelijk fijn katoen op doornen.

Artinja: barang soeatoe pěrkara jang tërlaloe soesah di dapati ataw hěndak měngěloewarkěn dia, maka hěndaklah dèngan pěrlahan dan děngan sabar sangat, sopaja djangan mèndjadi roesak ataw hilang sa'kali.

Beteekenis: de eene of andere zaak, die te moeijelijk is om te verkrijgen of om uit te brengen, laat die langzaam en met zeer veel geduld (geschieden), opdat zij niet bedorven worde of geheel en al verloren ga.

Aanm. De bedoeling van deze spreekwijze is: gelijk zeer fijn katoen, dat toevallig op doornstruiken is teregt gekomen, niet dan langzaam en met veel geduld daarvan is af te krijgen zonder te scheuren, zoo dient men ook geduld te gebruiken bij moeijelijk te verkrijgen zaken, die door overijling en geweld zouden bedorven worden of verloren gaan.

65. Sapěrti kambing di koeliti.

Als een schaap dat gevild wordt.

Artinja: njawa kéloevoar dari badan, ataw barang soeatoe jang tërlěbih sangat sakit di kěloewarkèn, ataw jang těrlěbih soesah mëndapat, ataw jang těrlěbith soesah di kěrrljakěn.

Beteekenis: (dit wordt gezegd) van de ziel, het ligchaam verlatende; of het een of ander dat uitermate pijnlijk om uit te halen (naar buiten te brengen), of zeer moeijelijk te verkrijgen, of uiterst moeijelijk uit te voeren is.

66. Moeloet di soewap pisang, pantat di kait oenak.

De mond gestopt met pisang-vrucht, de anus gestoken met een doorn.

Artinja: sa'orang běrkata di hadapan kita Téngan pěrkataün manis, akan tětapi di bělakang di oempatnja ataw di boewatkěnnja pakěrdjaän jang mĕndatëngkèn bahaja dan sa'bageinja.

Beteekenis: (als) iemand in onze tegenwoordigheid zocte 
woorden spreekt, doch achter (onzen rug) door hem wordt gelasterd of eene daad verrigt, die onheil aanbrengt en wat dies meer rij.

67. Sěbab tiada tahoe měnari, di katakěn lěmbab. Omdat (hij) niet dansen kan zegt (hij) 't is modderig. Aanm. De Maleijers dansen niet zoo als wij in besloten vertrekken of danszalen, maar in de open lucht op den naakten grond. Als de grond week en modderig is behoort hun dansen tot de onmogelijkheden, daar het hoofdzakelijk bestaat in een aanhoudend trappen en stampen met de voeten. Artinja: Šbab tiada ia tahoe měmboewat pakěrdjaàn itoe dan sa'bageinja di katakěnnja pěrkalkasannja tiadabaik, atan těmpatnja, ataw waktoenja tiada bětoel dan tiada baik. Beteekenis: daar hij het werk of iets van dien aard niet doen kan, zegt hij dat de werktuigen niet deugen, of dat de plaats of het tijdstip niet juist en niet goed is.

68. Habis oempan keroeng-keroeng tiadla dapat

$\mathrm{Al}$ het aas is op en men krijgt het vischje (dat keroengkeroeng genoemd wordt) niet.

Artinja: habis barang samowa di berrikěn, akan tětapi apa jang di kahěndaki itoe tiada dapat.

Beteekenis: al de zaken zijn weg geschonken, doch hetgeen verlangd werd, wordt niet verkregen.

69. Di tating sapěrti minjal jang pěnoh.

(Vrij vert.) Op de handen gedragen als eene pot vol olie. (Letterl. als olie die vol is.)

70. Sapěrti měnioep api di atas aĕr.

Gelijk vuur aanblazen op 't water (een brandend hout, dat op 't water drijft, met blazen aanhouden).

Artinja: di pěliharakěn sapěrti měměliharakěn djiwanja, déngan tiada sa'dikit pon berkoerang apa-apa.

Beteekenis: onderhouden worden zoo als (men) zijne ziel onderhoudt, zonder dat er iets, al ware 't ook een weinig, aan ontbreekt.

71. Běrapa pandjang landjoer bagitoelah salimoet. Zoo lang als de statuur des ligchaams is, zoo lang zij ook de deken.

Artinja: barang apa pěrboewatan, jang kita hěndak pĕrboewat itoe, hëndaklah bërkědar; djikalaoe měskin, tjara měskin, djikalaoe kaja, tjara kaja, sopaja sĕlamat. Beteekenis: welk werk wij ook willen verrigten, laat het 
naar onzen stand zijn; zijn wij arm, op de wijze der armen, zijn wij rijk, op de wijze der rijken, opdat het ons welga.

72. Djaoeh baoe boenga, ď̌kat baoe tahi.

Van verre bloemengeur, van nabij drekstank.

Artinja: tërlëbih baik bërkasih kasihan ataw bërsahabat dari djaoeh dari pada běrděkat děkat itoe, dapat tiada adalah barang pěrkara jang mëndatěngkèn běrsakit-sakitan hati.

Beteekenis: ' $t$ is veel beter elkander lief te hebben en met elkander bevriend te zijn van verre dan van nabij; (in 't laatste geval) kan 't niet missen of er is iets dat van weêrskanten misnoegen doet ontstaan.

73. Bintang di langit dapat di bilang, tětapi arang dimoeka tiada sĕdar.

De sterren aan den hemel kunnen geteld worden, maar van het koolzwart in 't aangezigt is men onbewust.

Artinja: běběrapa kadjahatan orang jang djaoeh sa'kalian dapat di lihatnja dan di bilangnja dan di kětahoënja, akan tětapi kadjahatannja sěndiri tiada tahoe dan sědar. Beteekenis: De vele ondeugden van lieden, die verre zijn, kunnen alle door hem gezien, geteld en geweten worden, maar zijne eigene ondeugden weet en beseft hij niet.

74. Toelakkěn tangga, kaki bërajoen.

Zoo de ladder weg gestooten wordt, slingeren de beenen. Artinja: di toelakkěn barang soeatoe, jang mëndalëngkën faidah, kamoedian kělak soesah akan datěng.

Beteekenis: als het een of ander, dat nut aanbrengt, wordt weg gestooten zal spoedig daarna de moeite komen.

75. Tahoe makan, tahoe mĕnjimpan.

Weten te eten, weten te bewaren.

Arlinja: apabila soedah mĕmboewat djahat, maka hëndaklah ia tahoe mënoetoep akan dia.

Beteekenis: Als hij kwaad gedaan heeft, laat hij weten het te bedekken.

76. Boewajan pon di gontjang, anak pon di tjoebit.

De wieg wordt wel bewogen, (maar) het kind wordt ook geknepen.

Artinja: pakërdjaän moeka-moeka kapada sa'orang di tëgahkèn dan kapada sa'orang di soeroehkën, mëndjadilah bërkalahi. 
Beteekenis : oogendienst, (een werk om iemands gunst te winnen) bij den eenen mensch tegengegaan en den anderen bevolen, veroorzaakt twist.

De volgende spreekwoorden zonder verklaring van het Maleisch.

\section{Itik di adjar bërěnang.}

Eene eend wordt zwemmen geleerd.

Aanm. dit is hoogst waarschijnlijk geen zuiver Maleische spreekwijze, maar uit het Javaansch overgenomen door Maleijers, die veel met Javanen verkeeren. In de taal luidt het

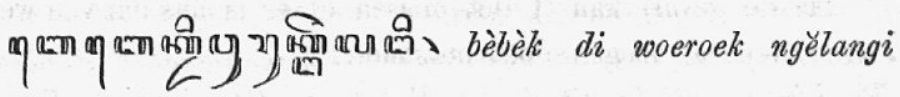
en de beteekenis daarvan vindt men opgegeven in de Jav. zamenspraken door C. F. Winter Sr., II deelen, pag.

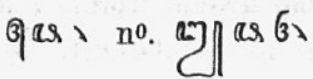

78. Orang jang tanam pokok nioer ${ }^{1}$ těrkadang-kadang tiada makan boewahnja.

Hij, die kokospalmen plant, eet dikwerf daarvan de vruchten niet.

Aanm. Omdat het bij de gewone soort meestal zeven jaren duurt eer zij vrucht dragen. Dit spreekwoord wordt gebruikt als men van lieden spreekt, die iets nuttigs tot stand hebben gebragt, waarvan anderen met de voordeelen gaan strijken.

79. Adakah aĕr jang pěnoh didalam tong itoe běrkotjak, mělainkěn aěr jang satěngah tong itoe djoega jang bërkotjak. Schudt ook het water in een vollen emmer? Integendeel, het water in een half vollen emmer is het dat schudt.

Aanm. Dit spreekwoord wordt gebruikt dan, wanneer wij zouden zeggen: Ledige vaten klinken het hardst. Het is ontleend aan het waterdragen, dat voor gemakkelijker gehouden wordt met volle emmers, daar de halfvolle te veel slingeren en schudden.

80. Adapon harimaoe itoe di takoeti orang oleh sěbab giginja maka djikalaoe tiada lagigiginja, apakah jang di takoetkěn orang akan dia?

1 De text heeft zoodat de uitspraak njur en dus eenlettergrepig
Corrector. zoude zijn. 
Den tijger vreest men om zijne tanden, maar zijn zijne tanden er niet meer, waarom zal men hem dan vreezen? Aanm. Dit spreekwoord wordt gebruikt van onderdrukkers gesproken, die, zoolang ze aan het bestuur zijn en de magt in handen hebben, worden gevreesd, doch, zoodra hun die magt ontnomen is, niet meer worden geteld.

81. Api itoe pada tatkala kětjilnja, ija itoe kawan, apabila běsar mëndjadi lawan.

Het vuur, als het klein is, is onze vriend, als het groot is wordt het onze vijand.

Aanm. Dit wordt veelal toegepast op de driften en neigingen van het menschelijk hart.

-82. Oempama boewah kapajang; di makan mabok, diboewang sajang.

't Is als met de kapajang-vrucht, wordt ze gegeten (dan wordt men) dronken; wordt ze weggeworpen, dat is jammer. Aanm. Dit wordt gezegd van iets dat te slecht is om gebruikt, en te goed om weggeworpen te worden.

83. Orang měngantoek di soeroengkěn bantal.

Een slaperig mensch een kussen onder (het hoofd) schuiven. d. i. Den hoogmoed en eigen waan van domme lieden nog meer voedsel geven door ze te prijzzen.

84. Ambil patinja, boewangkèn hampasnja.

Het zetmeel er van nemen, de vezels er van weg werpen. D. i. van een zekere zaak het kwade verwerpen en het goede behouden.

Aanm. Deze spreekwijze is ontleend aan de vervaardiging van araroet en sagoe, waarbij het zetmeel uit de plantenvezels door uitwassching en drooging wordt verkregen.

85. Apabila aĕr těnang, djangan di sangka tiada boewaja. Als het water stil is, laat dan niet gedacht worden, dat er geen krokodillen zij̄n.

D. i. al schijnt het uitwendig rustig en stil, zoo kan er toch wel gevaar bestaan.

86. Bërpikirkěn doesoennja itoe alam ini dan bilalang di sangkanja lang.

Zij denken dat hun dorp de geheele wereld is en een sprinkhaan meenen zij een kiekendief te zijn.

87. Balik bělakang, lain bitjara.

Men keert zich om en anders rijn de woorden.

Aanm. Dit wordt gezegd van iemand, die in onze tegen- 
woordigheid geheel anders spreekt dān in onze afwezigheid. Men zegt daarvoor ook wel: Di moeka lain di bělakang lain d. i. van voren anders, van achteren anders.

88. Barang siapa berani měngamang-amang ta'dapat tiada bërani mëlawan djoega.

Wie moed heeft om te dreigen, moet ook moed hebben om te wederstaan; d. i. wie met den mond iets kan, moet het ook met de daad kunnen.

89. Bilalang měndjadi lang dan pidjat mĕndjadikoera-koera dan tjatjing měndjadi oelar naga.

Een sprinkhaan wordt een kiekendief, een wandluis wordt een schildpad en een worm wordt een draak.

Aanm. Wij zouden zeggen: als niet komt tot iet, is 'talle- . mans verdriet.

90. Boedak boedak monjet mĕndapat boenga, adakah ia tahoe akan faidah boenga itoe?

$\mathrm{Als}$ apenkinderen bloemen vinden, kennen zij dan het nut van die bloemen?

Beteekenis: als iets kostbaars of wat kunstwaarde heeft in handen komt van lieden, die er geen verstand van hebben, dan zullen zij het bederven, even als de jonge apen de bloemen stuk plukken.

91. Bërapakah tingginja tërbang bangaoe itoe achirnja hinggap ia di bělakang kěrbaoe djoega.

Hoe hoog de reiger ook moge vliegen, ten laatste gaat hij toch op den rug eens buffels zitten.

Aanm. De beteekenis hiervan is: al is iemand nog zoo'n hoogvlieger, hij moet toch bij de dommen en eenvoudigen, bij de zoogenaamde werkezels teregt komen. De inlanders schrijven dezelfde eigenschappen aan den buffel toe als wij aan den ezel.

92. Barang siapa měnggali lobang, ia djoega tërprosok kadalamnja.

Wie een kuil graaft (voor een ander) valt er zelf wel in.

Aanm. Terrprosok is eigenlijk met den voet zonder opzet ergens doorheen trappen. Men moet hier denken aan een valkuil, welks opening met een ligt vlechtwerk van bamboe gesloten en een weinig aarde en gras overdekt is.

93. Barang tërgěnggam djatol tërlěpas.

Het in de vuist gehoudene valt er uit; d. i. wat men met zekerheid meende te bezitten, verliest men. 
94. Běrani maloe, takoet mati.

Moed hebben om te schamen, vreezen om te sterven;d.i. liever smaad en schande dragen dan zich in de bres stellen voor waarheid en regt.

95. Tiada sěbab hıjam sa'ekoer měngatahoë hari siang. Niet omdat één haan het weet wordt het dag, d.i. belangrijke zaken zouden toch wel tot stand komen, al heeft daarvan ook een ingebeelde gek den mond niet vol.

96. Tiap-tiap batoe, jang adla bĕrgoelik sělaloe di dalam soengei itoe, tiadalah di hinggap oleh loemoet akan dia. Elke steen, die voortdurend in de rivier heen en weêr rolt, zal niet door kroos (of zoetwater-polypen?) bezet worden; d. -i. hij, die veel moeijelijkheden in de wereld ondervindt, wordt niet zoo ligt met het kwade besmet.

97. Tali jang tiga lěmbar itoe ta'soewany-soewang poetoes. Een drievuldig snoer zal niet ligt verbroken worden.

98. Tiada rotan, akar pon bèrgoena.

Is er geen bindrotting, wortels kunnen ook dienen.

Aanm. De rotting vervult bij de inlanders de plaats van touw. Hebben zij geen rotting dan gebruiken zij voor hetzelfde doel de luchtwortels van sommige boomen en slingerplanten, die zeer taai en lenig zijn.

99. Tiada makan nangkanja, maka kěna gětahnja.

Geen nangka-vrucht eten en toch met hare gom besmet worden; d. i. geen deel genomen hebben aan iets en toch de gevolgen daarvan moeten lijden.

Aanm. Uit de schil en den steel der nangka-vrucht vloeit een zeer sterk klevende gom, die voor vogellijm gebruikt wordt en onuitwischbare vlekken in de kleederen makt. Deze gom is de schaduwzijde der anders aangename vrucht. 100. Tangan jang tjëlaka kërdja djatoh.

De ongelukkige hand doet vallen.

Dit wordt gezegd van een ongeluksvogel, wien alles tegenloopt.

101. Djaoehari djoega jang měngěnal manikam.

Een juwelier kent de juweelen wel; d. i. alleen een man van 't vak kan de dingen beoordeelen, die tot dat vak behooren.

102. Djikalaoe běrapa banjak pon andjing měnjalak, boekit bolehkah roentoeh?

Al blaffen nog zooveel honden, kan een berg daardoor omvallen?

103. Djikalaoe sa'pohon kajoe banjak akarnja lagi těgoh, apakah di takoetkèn riboet? 
Als een boom vele en sterke wortels heeft, waarom zou hij den storm vreezen?

104. Djikalaoe tiada dapat di baiki, tëtapi djangan di pětjahkèn. Kan het niet hersteld, laat het daarom niet verbroken worden; d. i. kunt ge er geen goed aan doen, doet er dan ten minste geen kwaad aan.

105. Djikalaoe di hoeloe aĕrnja kěroeh, dapat tiada dihilirnja pon kerroeh djoega adanja.

Als het water boven (aan den oorsprong) troebel is, dan kan 't niet anders of het zal ook beneden troebel wezen.

106. Djikalaoe měnampi, djangan toempah padinja.

Als (men) want, dan geeu rijst gestort; d. i. werp met het kaf het graan niet weg.

107. Di těmpat tiada lang, kata bilalang: akoelah lang.

Waar geen kiekendieven zijn zegt de sprinkhaan: $i k$ ben kiekendief; d. i. in het land der blinden is éénoog koning.

108. Di děngar ada, di pakei tidak.

Naar men hoort is 't er, wil men 't gebruiken dan is 't er niet. (Vrij vert.)

109. Dapat tiada tiap-tiap soeatoe itoe kěmbali ia kapada asalnja. 't Kan niet missen of elk ding keert tot zijn oorsprong weder.

110. Doedoek saperti katak di bawah těmpoeroeng.

Zitten als een kikker onder een kokosdop.

Dit wordt gezegd van iemand, die in benaauwdheid zit en niet weet hoe er uit te komen.

111. Děngarkěn tjaritra boeroeng, anak di pangkoe di lëpaskèn. Al luisterende naar het verhaal eens vogels het kind van den schoot laten vallen; d. i. gewigtige zaken voor beuzelingen laten varen.

112. Dahoeloe timah, sa'karang bësi.

Vroeger lood, nu ijzer; d. i. vroeger was hij zacht, tegenwoordig is hij streng.

113. Sapěrti pinang di bělah doewa.

Als een in tweeën gespleten areka noot; d. i. zij lijken op elkander als 't eene ei op 't ander.

114. Sapěrti raboek déngan api.

Als tonder en vuur; d. i. als vuur bij stroo.

115. Sapěrti ilik měněngarkěn goentoer.

Als een eend die naar den donder luistert.

Aanm. Wij zeggen daarvoor: hij heeft de klok hooren luiden, maar weet niet waar de klepel hangt. 
MALEISCHE SPREEKWOORDEN EN SPREEKWIJZEN.

Als het dondert, zitten de eenden onder een zacht gekwaak bijeen met den kop schuin en het eene oog naar den hemel gerigt naar den donder te luisteren, alsof ze het volmaakste begrip daarvan hadden.

116. Siapa bĕrani měnangkap harimaoe?

Wie heeft den moed om een tijger met de handen an te pakken? d. i. wie durft de kastanjes uit het vuur halen?

117. Sapěrti awoer-awoer di tarik soengsang.

Gelijk bamboe tegen het beloop der takken is voortgetrokken. Aanm. Tarik soengsang wordt gezegd van alles wat verkeerd, 't achterste voor, 't onderste boven, of bij de beenen wordt voortgetrokken. Een bamboe aldus voort te trekken is zeer moeijelijk, omdat alles in de takken blijft hangen en zij overal blijven haken.

118. Sěsal dahoeloe pěndapatannja, sěsal kěmoedian itoe soeatoepon tiada apa goenanja.

Berouw vooraf heeft zijn voordeel, maar berouw daarna is volstrekt zonder nut.

119. Sa'ekoer tjaljing měnělan naga.

Een worm slikt een draak in.

120. Sapěrti tělor di hoedjoeng tandoek.

Als een ei op de punt eens horens. Dit wordt gezegd om de moeijelijkheid van een of ander werk aan te duiden.

121. Sapoeloeh kapal datëng pon andjing bërtjawat ekoer djoega. $\mathrm{Al}$ komen er ook tien schepen, de honden loopen toch met den staart tusschen de pooten.

122. Sapěrti těboe, aёrnja di makan, hampasnja di boewang.

Gelijk aan suikerriet; het sap wordt gedronken (lett. gegeten), de vezels worden weg geworpen.

Dit sprw. is gelijk aan no. 84 .

123. Sapěrti ombale mëmbanting dirinja.

Gelijk golven, die zich zelven slaan.

124. Sarang oenam di masokki kětam mĕndjadi oemang oemang. Als in het nest der zeeslakken een krab gedaan wordt dan komt er opschudding.

Aanm. Wij zouden zeggen: als er een vreemde eend in de bijt komt enz.

125. Patah kěmoedi děngan ěbamnja.

Stuk is het roer met de roerboom; d. i. alle hoop is verloren.

126. Pělandoeklah loepakěn djërat, tětapi djërat tiada měloepakèn pělandoek adanja. 
Het dwerghert is ' $t$, dat den strik vergeet, maar de strik vergeet het dwerghert niet.

127. Prahoe papan běrmoewat intan.

Een planken schuit met diamanten geladen; d. i. een kostelijke schat in een aarden vat.

128. Pasang pělita di langgar tikoes.

Steek de lamp aan, zij wordt door een rot omver geloopen.

129. Kajoe di katakěn batoe dan langit hěndak di tjapei děngan tangan.

Hout wordt steen genoemd en den hemel wil men met de hand vatten.

Aanm. Hiermede wil men de domheid en verwaandheid van iemand aantoonen.

130. Kapal satoe nakhoda doewa.

Een schip met twee gezagvoerders.

Aanm. Hiermede zinspeelt men op elke zaak, waarin twee personen om strijd hun gezag willen handhaven en haar daardoor te gronde rigten.

131. Laksana pěntjalang tërsarat, tiada katimoer, tiada kabarat. Gelijk een te zwaar geladen vaartuig (pentjalang genoemd), dat noch oost noch westwaarts kan; d. i. een met zorg beladene, die niet weet waarheen zich te wenden.

132. Lajang-lajang poetves talinja.

Een vlieger, waarvan het touw gebroken is. De beteekenis hiervan is als die van $n^{0} .125$.

133. Měngěmbalikkěn manikam itoe kadalam tjëmboelnja.

Het edelgesteente weder in zijn doosje doen; d. i. zaken of personen, die bij elkander behooren, weder tot elkander brengen.

134. Mèmboewang garam kadalam laoet.

Zout in zee werpen; d. i. monnikenwerk doen.

135. Makin banjak orang makin banjak niat.

Hoe meer menschen, hoe meer bedoelingen; d. i. veel hoofden, veel zinnen.

136. Mémĕgang běsi panas.

Heet ijzer in de hand houden.

137. Mahal di beli, soekar di tjahari.

Duur om te koopen, moeijelijk om te vinden. Dit wordt gezegd van iets zeldzaams, waarvoor wij zeggen: Het zijn witte raven. 
138. Maloe kalaoe anak harimaoe měndjadi anak koetjing. 't Is schande als een tijgerjong een kattenkind wordt.

139. Minoem aër bërasa doeri.

Water drinken, doornen smaken (of proeven, gevoelen). Dit zegt men om de hevigheid eener ziekte aan te duiden of ook in de beteekenis van: brood der smarte eten.

140. Měnioep soeling berrboenji bangsi, maka bangsi di tioep těrpatah-patah.

Blaast men op de fluit dan speelt de flageolet, en wordt de flageolet geblazen dan breekt ze aan stukken.

141. Mata tidoer bantal měndjaga.

Het oog slaapt en het kussen houdt de wacht.

142. Matilah koeman kěna pělëntik, sa'kalian alam limpah darahnja.

Een insektje wordt met de vingers dood geknipt, de geheele wereld wordt overstroomd met deszelfs bloed; d. i. veel geschreeuw voor niet-met-al.

143. Harimaoe mati mĕninggalkèn bělang; Gadjah mati mëninggalkěn toelang.

Sterft de tijger, hij laat vlekken na; sterft de olifant, hij laat beenderen na; d. i. na iemands dood kan men zien wat hij was bij zijn leven.

144. Hoetang ěmas dapat di bajar, hoetang boedi di bawa mati adanja.

Schuld in goud kan worden betaald; de schuld des verstands (d. i. wat men aan verstand te kort gekomen is) voert de dood mede (naar de eeuwigheid.)

145. Hilang bini, boleh dr tjahari; hilang boedi, badan tjëlaka.

Eene vrouw verloren, die kan gezocht worden; d. i. wijsheid verloren, ongelukkig het ligchaam!

146. Ilmoe dan akal di halei balei itoelah tanda orangjang lalei. Als wetenschap en verstand verwaarloosd worden is dit een teeken van een beuzelachtig mensch.

147. Lanqit bĕrkělikir, boemi bĕrtambirang; Salah-salah pikir mëndjadi hamba orang.

De hemel met een kransstrop, de aarde met een scheepswant; Door gebrekkig nadenken wordt men eens anders knecht. Aanm. De eerste regel van dit sprw. in verband gebragt met de laatste, geeft geen zin. De reden daarvan is, dat het berijmd is op de wijze der pantons. Zie daarover de 
Handleiding bij de beoefening der Mal. taal- en letterkunde, door Dr. J. J. de Hollander, 3e dr. pag. 296.

148. Kamana toempahkěn koewah kalaoe tidakkěn nasi.

Waarop zal de saus uitgegoten worden als er geen rijst is; d. i. wat baat het dat iemand schatten vergadert, als hij moet sterven zonder erven; of wat baat iemand zijne geleerdheid, als hij ze aan niemand kan kwijt raken?

149. Goeroe këntjang běrdiri, anak moerid kěntjang bërlari.

De meester kan 't met staan, de scholieren met 't weg loopen uithouden; d. i. zoo ijverig de opziener bij eenig werk is om daartoe aan te drijven, zoo ijverig zijn ook de arbeidslieden om er zich van af te maken.

150. Poenggoer toembang bělatoek měnoempang mati.

De vermolmde tronk valt om, de specht woont in het sterfhuis. Dit wordt gezegd van iemand, die bij een ouden rijkaard is gaan inwonen om bij zijn overlijden zijne nalatenschap magtig te worden, en die ook werkelijk daardoor heeft verkregen.

151. Bagimana hari ta'hoedjan, katak bĕtoeng di dalam tělaga bèrtareak sa'laloe.

Hoe zou er van daag geen regen zijn, daar de bětoengkikker (een soort van gele kikker met zwarte spikkels) voortdurend kwakt; d. i. hoe zou de vogel heden niet door de kat gepakt zijn, daar hij al zoo vroeg van morgen heeft gezongen.

152. Bagimana pohon tidakkèn toembang di panah halilintar, sěbab baloeng koelit ada di batangnja.

Hoe zou de boom niet omvallen als hij door den bliksem wordt getroffen, want er is een gat in zijn stam; d. i. 't was te verwachten dat hij door dit onheil vallen zou, want reeds lang stond hij wrak.

Aanm. Door baloeng koelit verstaan de Maleijers een groot gat overlangs in den stam eens booms, over welks randen de bast naar binnen is gegroeid, zoo als men dit aan holle boomen meestal waarneemt.

153. Pada tatkala rěboeng tiada di patahkěn, maka koetika soedah měndjadi awoer-awoer apakah goenanja?

Toen het een bamboe-uitspruitsel was werd het niet afgebroken, en nu het volwassen bamboe is geworden, waartoe is het nut?

Aanm. Wij zouden zeggen: men moet den boom buigen 
als $\mathrm{h}$ jong is. Men moet hierbij bedenken, dat de jonge bamboe-loten, fijn gesneden en gestoofd, eene welsmakende groente opleveren en eene zoogenaamde rijsttafel niet ontsieren. Ook maakt men daarvan een "aangenaam tafelzuur. Een w inig te oud geworden kan men ze gerust laten staan want dan zijn de zachte, suikerhoudende vezels reeds in houtvezels overgegaan.

154. Gadjuh mëmamah aris, baik di ikat këra jang kětjil mëmakan boewuh kajoe.

De olifant kaauwt de jonge loten (der boomen) ('t is daarom) goed dat hij gebonden worde, (opdat) de kleine apen de boschvruchten kunnen eten; d. w. z. De grooten moeten in hunne hebzucht gefnuikt worden, opdat de kleine man ook wat kan te eten krijgen. De constructie van dit sprw. is zeer onvolmaakt, doch ik geef het weder zoo als ik het in een handschrift gevonden heb.

155. Moeloet bava madoe, päntat bawa sěngat.

De mond brengt honig, het achterste brengt een angel.

Aanm. Dit sprw. is ontleend aan de bijen en wordt gebruikt om lieden aan te duiden, die zich in onze tegenwoordigheid lief voordoen, doch naderhand blijkt, dat zij ons ongeluk hebben gezocht.

156. Sapěrti mĕmaniljat tërkěna saroeda.

Gelijk (iemand die) klimt en aan de doornen blijft haken. Aanm. Eigenlijk is saroeda een doornenkrans, die om het midden van den stam der kokospalmen gemaakt wordt van de scherpe, vaneen gespleten houtvezels van den niboengboom. Deze vezels worden met de punten naar boven als een krans om den stam gebonden, ter halver hoogte van den boom. Wanneer des nachts iemand daarin klimt om vruchten te stelen vereischt het te veel tijd om den boom daarvan eerst te ontdoen. De dief klimt voort, doch wee hem! zoo hij bij het afdalen het ongeluk heeft aan die stekels te blijven hangen, want dan komt hij niet zoo spoedig los en kan zich zwaar bezeeren.

De beteekenis van deze uitdrukking ts: Iets ondernemen en er niet zonder kleerscheuren afkomen.

157. Sapěrti porok di nalikèn.

Als een kokosdop in twee keeren raak.

Aanm. Dit gezegde is ontleend aan een spel, bij de Maleijers op Pěnjěngat in zwang. Men gebruikt daarbij twee 
geheele doppen van kokosnoten, die door een daarin gemaakt gaatje van hunnen inhoud worden ontlast en uitgehoold. Één daarvan ligt stil, de andere wordt door eene wrijvende beweging tusschen de beide voetzolen des op den groud zittenden spelers, zoodanig geworpen of voortgestuwd, dat de stil liggende daarmede wordt geraakt. Geschiedt zulks in éénen keer, dan noemen de Maleijers dit ratoes, in twee keeren nali, in drie keeren makan lawan en zoo hij in 't geheel niet geraakt kan worden loentjas.

Deze spreekwijze wordt gebruikt van iets, dat men door eene herhaalde poging magtig wordt.

158. Sapěrti tempoeng měnoedjoe djih.

Gelijk een werpsteen op het mikstokje afgaat. Dit is mede ontleend aan een spel der Maleijers, waarbij zij met een ronden, gladden steen naar een in den grond gestoken stokje werpen om dat te doen omvallen. Men gebruikt dit woord om aan te duiden, dat iemand vast en snel op zijn doel afgaat.

159. Sapěrti pinggan děngan mangkok, salah sa'dikit hëndak bërantok.

Gelijk het schoteltje met het kopje, een weinig verkeerd (gehouden) willen (ze) tegen elkander stooten.

Dit sprw. wordt gebruikt sprekende van twee personen, die op elkander naijverig zijn, en daardoor telkens twist krijgen.

160. Sapěrti pinang poelang katampoek.

Gelijk een areca-noot terugkeert tot de vruchtstoel.

161. Sapěrti sirih poelang kagagang.

Gelijk betelblad terugkeert tot het bladsteeltje.

Beide deze spreekwijzen worden gebruikt als men spreekt over geringe lieden, die groot zijn geworden, doch weder tot hun vorigen staat terug vallen.

162. Sapěrti koetjing berakkěn ramboet.

Gelijk eene kat, die haar afgaat.

Aanm. Dit wordt gezegd van iemand, die alles ten halve doet en niets geheel afwerkt. De spreekwijze is ontleend aan eene kat, die een zeker dier met huid en haar opgegeten heeft en daarvan de lastige gevolgen moet ondervinden.

163. Bagei tandoek běrsindei gading.

Gelijk een horen met ivoren geledingen.

Dit zegt men van twee personen of twee volken, zoo als b. v. de Nederlanders en de Maleijers, die met elkander 
verbonden zijn, doch waarvan de eene edeler is dan de andere. 164. Sapěrli pasir di těpi pantei, maka tatkala timpas aĕr bolehlah kita pěrbahageikèn.

Gelijk het zand aan den oever; als het water terug geloopen is kan het door ons gedeeld worden.

Aanm. Dit sprw. wordt gebruikt als men den toorn van een hooggeplaatst persoon of een vorst heeft ondervonden, en men bedoelt daarmede dat, na het bedaren van dien toorn, de geschikte tijd daar is om weêr in de gunst te komen, even als het zand, nadat het water is afgeloopen, alleen geschikt is om daarin figuren te teekenen, want zoo lang het door den golfslag wordt beroerd is zulks onmogelijk.

165. Supěrti doerian déngan mantimoen.

Als de doerian-vrucht met den komkommer; d. i. twee zaken of personen behooren bij elkander als die beide vruchten.

166. Sapěrti tëlor doewa sa'banđloeng, pětjah satoe, pëtjah kadoewa. Als twee aan elkander vast zittende eijeren, breekt een dan breken beide.

Aanm. Deze spreekwijze is ontleend aan eene eigenaardigheid van de hagedis-eijeren, want andere, uitgenomen die van insekten, kleven nooit aan elkander, wèl vruchten, bladen bloemen en ook zelfs levend ter wereld komende wezens. De beteekenis is: Als iemand zijnen broeder vijandig is en hem in 't ongeluk stort, dan zal ook hij zeker ongelukkig worden.

167. Sapěrti gadjah dèngan sangkalanja.

Gelijk een olifant met zijn voetbeugel; d. i. een groot en magtig man met "een blok aan 't been."

168. Sapěrti lot déngan mërkah.

Gelijk een dieplood met de merkteekenen.

Aanm. Om dit gezegde te begrijpen moet men zich een dieplood voorstellen, aan welks lijn de vademen met daaraan bevestigde witte lapjes zijn gemerkt. Men zegt zulks van een kundig mensch, die door zijne kundigheden de dommen vooruit gaat en hen achter zich medevoert, even als het lood door zijne zwaarte 't eerst zinkt en de lijn met die merken naar de diepte trekt.

169. Oempama aĕr di gěnggam ta'tiris.

Gelijk water (zóó) in de vuist gehouden (dat het) niet doorsijpelt; d. i. zóó gierig en vasthoudend, dat men op een halve cent dood blijft. 
170. Sapěrti poetjoek děngan pělěpah.

Gelijk een uitspruitsel bij een volwassen palmtak.

Aanm. Dit wordt gezegd van een nuttig doch arm man, vergeleken bij een onnutten rijkaard. De jonge uitspruitsels der palmen zijn eetbaar, doch hebben nog geen bladeren. De volwassen takken echter kunnen niet gegeten worden en spreiden zich wijd en breed uit.

171. Kalaoe karbaoe sa'kandang dapat di kawalkěn, manoesia sa'orang tiada dapat di mäloemkèn.

Op een hok vol buffels kan men passen, maar één enkel mensch kan niet tot rede gebragt worden.

172. Sapěrti méněpoeng tiada bërběras.

Gelijk meel stampen zonder rijst te hebben; d. i. iets ondernemen zonder daarvoor de noodige kennis of het vereischte geld te bezitten.

173. Tělěntang bërisi aĕr, tiharap bërisi tanah.

Achterover liggende vol water zijn, voorover liggende vol aarde.

Dit is ontleend aan een op den grond liggenden kokosdop en beteekent: Bemoei $u$ niet met eens anders zaken, want keer hem van den eenen naar den anderen kant, altijd zal er iets aan hem wezen, dat niet goed is.

174. Sapěrti gěroek děngan sisir.

Gelijk de houten lijst van een weverskam met de kam; d.i. zoo onafscheidelijk zijn zij verbonden.

175. Di këntjanglěn sanloeng, karap dan tjanang di mainkěn. Wordt het pedaal aangedrukt dan komen het weefgetouw en houten' balansje in speling.

Aanm. Dit sprw. is moeijelijk goed te vertalen. Sandoeng is de trapper of het pedaal van een weefmachine, zoo als de Maleijers die gebruiken. Dit werktuig verschilt zooveel met dat der Europeanen, dat ik elk deel daarvan niet goed benoemen kan. Sandoeng is hoogst waarschijnlijk uit het Javaansch overgenomen, want de Maleijers zeggen daarvoor meestal tangga, nml. in de beteekenis van pedaal. Karap is mede een onderdeel van eene weefmachine en bestaat uit twee stel elk van vier ronde stokken, gěligin genoemd, waarvan elke vier met eene menigte dunne touwtjes zijn bespannen. Beide stellen hangen aan de uiteinden van een houtje, dat als eene balans werkt en ze doet op en neder gaan. Dit houtje wordt tjanang genoemd. Wordt het pedaal 
nu met den voet aangedrukt dan komen die beide zaken in werking.

Dit sprw. wordt gebruikt als men spreekt van personen, die niets uitvoeren, maar door geld of bedreiging of aansporing worden overgehaald om iets te verrigten.

176. Di toeroenkěn bělěbas, pakan digoeloengkěn děngan pěsanja. Het spouwhout (of de weversliniaal) wordt naar beneden gedrukt, de inslag wordt opgerold met de houten rol.

Aanm. Ook dit sprw. is duister, door dat de namen der details van eene weefmachine zoo moeijelijk zijn te vertalen als men bij niemand kan informeren hoe die details in onze taal worden genoemd. Mij schiet dus niet anders over als ze te omschrijven.

Bělěbas is een lang; plat hout in den vorm van eene liniaal, dat door de weefsters tusschen de draden wordt gestoken om die van elkander te houden.

$P \breve{s a}$ is de houten rol, waarop het afgeweefde doek gewikkeld *wordt.

Dat die liniaal wordt neêr gelaten en de inslag met die rol te zamen wordt opgerold is, omdat het weven is afgeloopen. Deze spreekwijze wordt dan ook gebruikt om aan te duiden, dat een werk beëindigd is en alle zaken aan een kant zijn gedaan.

177. Sapërti soetra di dalam likasan.

Gelijk zijde op den haspel; d. i. gelijk het zijden-garen op een haspel geheel geschikt is om voor het weven gebruikt te worden, daar het behoorlijk is gesponnen en glad gemaakt; zoo is ook iemand, die in zijne jeugd goed is onderwezen, geschikt om als een bruikbaar lid van de maatschappij op te treden.

178. Sapěrti kapoer di hoedjoeng těloendjoek.

Als kalk op den top van den wijsvinger; d. i. het een of ander geliefd werk is zoo gemakkelijk als het houden van een weinig sirih-kalk op den top van den wijsvinger, om daarmede het sirih-blad te besmeren.

179. Pětjah kapi, poetoes soewadji.

Gebroken is het hijschblok, stuk is de broek; d. i. het een of ander voornemen wordt verijdeld, b. v. men wil gaan wandelen doch komt een vriend tegen, met wien men weêr naar huis keert; of een schip gaat onder zeil, maar krijgt storm, waarom het weêr binnen loopt. 
Deze spreekwijze is ontleend aan de manier, waarop een anker wordt opgeheschen en aan den voorsteven bevestigd. Aan dat anker is een broek, dat is een touw, waaraan twee oogen gesplitst zijn. In die oogen wordt de haak van het blok geslagen. Indien nu een vaartuig onder zeil is en dat blok of die broek breekt, dan loopt het anker af en het schip kan niet voortgaan.

180. Sapěrti saloedang měnoelak majang.

Gelijk een bloemhulsel den kokosbloemtros weg stoot.

Dit zegt men b. v. van lieden, die een kind hebben aangenomen, door hetzelve met ondank worden beloond en het daarom weêr van zich afstooten.

Dit sprw. is ontleend aan den bloemtros der kokospalmen, die door een groot, langwerpig, schuitvormig hulsel wordt beschermd. Deze tros wordt door het rijpen der vruchten hoe langer hoe zwaarder, buigt zich meer en meer van dat hulsel af naar beneden en valt eindelijk ter aarde.

181. Sa'koetoek bëras basah, di tampi ta'bërlajang, di indang ta'bèrantah, hoedjoengnja tiada di soedoe oleh itik.

Een maatje natte rijst, gewand, laat geen kaf vliegen, heen en weêr geschud op eene wan heeft het geen ongepelde korrels, het gruis er van wordt door de eenden niet gelepeld (met hun snavel opgeschept.)

Dit sprw. is ontleend aan de wijze, waarop men de gepelde rijst schoon maakt eer men ze kookt. Zij wordt daartoe eerst gewand op eene wan, die een ronde, platte vorm heeft, vervolgens heen en weêr geschud opdat zij zich uitspreide en de ongepelde korrels zigtbaar worden. Die korrels werpt men er uit als ook het fijne gruis, dat tot voeder voor eenden en kippen wordt gebruikt. Is die rijst nat, dan kan men ze niet uitzuiveren, en is ze dit door zeewater geworden, wat hier de veronderstelling is, dan lusten zelfs de eenden het niet.

Bij zulk een onbruikbaar maatje rijst vergelijkt men iemand, die tot niets deugt. De maten, waarmede rijsst gemeten wordt zijn: een kojan $=40$ pikoel, een pikoel $=100$ kati of 20 gantang of 2 parah, een parah $=10$ gantang, een gantang $=4$ tjocpak, een tjoepak $=2 \mathrm{kal}$, een $k a l=2$ koetoek, een koetoek $=2$ ling, een ling $=2$ gĕngam.

182. Hidoeng ta'mantjoeng, pipi těrsoeroeng-soeroeng. 
De neus is niet gebogen (en toch) zijn de wangen bol (neêrhangende van dikte); d. i. Men heeft de kenmerken niet van hooge afkomst ${ }^{1}$ en toch neemt men het air daarvan aan.

183. Bělom doedoek. bĕrlandjoer dahoeloe.

Nog niet gezeten zijn de beenen al uitstrekken; d. i. Verteringen maken van gelden, die men nog ontvangen moet, of op rekening van eene betrekking, die men hoopt te krijgen.

1 De Maleijers beschouwen de Arabieren als het voornaamste volk der aarde. Daar deze met haviksneuzen zijn bedeeld, geldt zulk een neus voor een teeken van voornaamheid of van Arabische afkomst, wathetzelfde is.

DRUKF O U T EN.

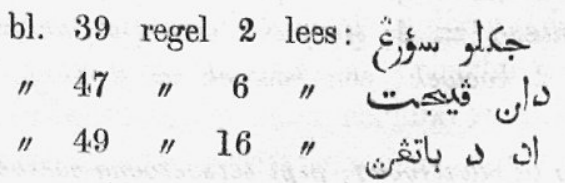

